\title{
El poeta sefardí de Salónica Šelomó Šalem: nuevos datos biográficos y sus crónicas sobre los cafés cantantes de la Salónica de principios del siglo XX
}

\author{
Elena Romero \\ ILC-CSIC (Emérita) \\ ORCID 0000-0003-4798-0459
}

El presente artículo está dedicado a la figura del poeta y periodista salonicense Šelomó Šalem (1873-1910), quien fue colaborador del periódico La Época. Se examinan los datos que sobre su persona ya han publicado otros autores; se aducen nuevos datos biográficos a los ya conocidos mediante textos publicados por él mismo y por algún otro poeta de la época. Asimismo se examina su obra poética publicada en el citado periódico, sus dos recopilaciones de poesía tituladas La gavilla y Cuaderno de poesía, y se dedica un apartado al estudio y edición de cuatro de sus poemas que constituyen una innovación para la época: un a modo de cartelera de espectáculos sobre las atracciones de los cafés cantantes de Salónica en 1900.

PaLABRAS CLAVE: Literatura sefardí; poesía sefardí; periodismo sefardí; edición de textos sefardíes aljamiados; el periódico La Época de Salónica; las colecciones de poemas La gavilla y Cuaderno de poesía; espectáculos y cantantes.

The Sephardic Poet Shelomoh Shalem: New Biographical Data and his Chronicles on the Cafés-Chantantes in Salonika at the Beginnings of the 20th Century.- This article deals with the figure of the Salonika poet and journalist Shelomoh Salem (18731910) who collaborated with the newspaper La Época. His biographical data published by other scholars are first revieweb, and new data extracted from his texts and other poets'

${ }^{*}$ El presente artículo ha sido elaborado en el marco del Proyecto de Investigación del Plan Nacional «Sefarad, siglo XXI (2017-2020): Edición y estudio filológico de textos sefardíes», financiado por el MINECO [ref. núm. FFI2016-74864-P]. Una versión muy abreviada del mismo fue presentada como comunicación en la XIX British Conference on Judeo-Spanish Studies, celebrada en Londres (Queen Mary) los días 5-7 de septiembre de 2016.

*"elena.romero@cchs.csic.es

Copyright: () 2017 CSIC. Este es un artículo de acceso abierto distribuido bajo los términos de una licencia de uso y distribución Creative Commons Attribution (CC-by) España 3.0. 
are added. Also, his poetic work appeared in the aforementioned newspaper together with his two poems collections La gavilla and Cuaderno de poesía are examined. Last, we edit and study four innovative poems written by Salem that constitute some kind of spectacle billboard on the shows offered at the 1900-Salonika's Cafés chantants.

Keywords: Sephardic Literature; Sephardic Journalism; Sephardic Poetry; Edition of Sephardic aljamiado texts; Poems collections La gavilla and Cuaderno de poesía; Salonika's newspaper La Época; shows and singers.

\section{Generalidades}

Como ya he dicho en diversas ocasiones ${ }^{1}$, la prensa judeoespañola acogió frecuentemente en su seno los nuevos géneros literarios que desde los finales del siglo XIX empezaron a producir los sefardíes del todavía Imperio Otomano. Uno de esos géneros es el que he llamado «poesía de autor» ${ }^{2}$, para distinguirla de otros géneros poéticos castizos, como los tradicionales del romancero y del cancionero, y también el de las coplas.

$\mathrm{Al}$ respecto de estas últimas cabe recordar que, aunque también son poemas que suelen tener un autor conocido, con frecuencia su nombre se olvida para pasar los textos a ser patrimonio de la colectividad que las lee y las canta. Asimismo el amplísimo acervo poético de las coplas se diferencia esencialmente de estos «poemas de autor» por las formas estróficas en que se escriben unas y otros ${ }^{3}$.

Pues bien, con la llegada de los aires de la modernidad occidental a tierras del Levante de Europa, muchos sefardíes cultos, educados en las

${ }^{1}$ Vid. Elena Romero, La creación literaria en lengua sefardí (Madrid: Mapfre, 1992) pág. 179, e «Historia y literatura», en Sefardíes: Literatura y Lengua de una Nación Dispersa, ed. Elena Romero, coords. Iacob M. Hassán y Ricardo IzQuierdo Benito (Cuenca: Ed. de la Universidad de Castilla-La Mancha, 2008) págs. 155-192: 185.

${ }^{2}$ Vid. Romero, Creación, págs. 212 y 214-217.

${ }^{3}$ Sobre la autoría de las coplas, vid. Romero, Creación, págs. 156-158; y sobre sus esquemas estróficos vid. Elena ROMERo, «Formas estróficas de las coplas sefardíes», en Poesía estrófica: Actas Primer Congreso Internacional sobre Poesía Estrófica Árabe y Hebrea y sus Paralelos Romances, eds. F. CORRIENTE y Á. SÁEnz-BAdILlos (Madrid 1991) págs. 259-278; Creación, págs. 148-153, y «Las Coplas sefardíes: Vestigios e innovaciones de la poesía medieval hispana», en Antes se agotan la mano y la pluma que su historia, Homenaje a Carlos Alvar, eds. Constance CARTA, Sarah Finci y Dora Mancheva (2 vols., Cilengua - Fundación de San Millán de la Cogolla 2016) vol. I, págs. 895-916. 
escuelas francesas e italianas que se fundan en los Balcanes por aquellas épocas, se lanzan a escribir, con mejor o peor fortuna, poemas «a la moderna», que en buena medida se publican en las páginas de los periódicos y algunas veces en libros sueltos, muchos de los cuales son a su vez recopilaciones de textos publicados anteriormente en la prensa ${ }^{4}$. Tal es el caso, por ejemplo, de Šelomó Šalem (o quizá Salem ${ }^{5}$ ), poeta del que voy a ocuparme en este artículo. Puede verse al final el Glosario.

\section{2. ŠSLOMÓ ŠAleM: DATOS BIOGRÁfICOS}

Probablemente la primera vez que el nombre de Šelomó Šalem saltó los límites de la Salónica del todavía Imperio Otomano al occidente europeo fue de la mano de Ángel Pulido, quien nos dice de él lo siguiente:

Ilustrado poeta, amante de la literatura, es el Sr. D. Salomón Salem, empleado en la C.ía Otomana de aguas de Salónica, quien nos ha favorecido con estimables composiciones. De sus cartas recogemos los siguientes consejos ${ }^{6}$.

Consejos que consisten en tres recomendaciones de lo que tenía que hacer España para conseguir que el judeoespañol sobreviviera en Saló-

\footnotetext{
${ }^{4}$ Vid. Romero, Creación, págs. 214-217.

${ }^{5}$ La duda sobre la correcta pronunciación de su apellido me la ha sembrado mi buen amigo y colega Shmuel Refael, quien recientemente me ha dicho que él ha escuchado el apellido con la forma que indico en el paréntesis. Sin embargo, véase en nota 86 infra, el juego de palabras que allí comento con el nombre y apellido de nuestro autor. Item más, en la versión resumida y en letras latinas del artículo de Daout LEvi, «Sequirá 'al mosadot haquehilá beSaloniqui tr"l - t”s (1870-1940)», en Zijrón Saloniqui ..., redactor David A. ReCANATI (Tel Aviv 1986) vol. II, págs. 127-142 (resumen en judeoespañol en letras latinas: «Las institutiones de la communita (1870-1940)», en págs. 20-21): págs. 21 y 134, se menciona a un Emanuel Chalem, muerto en París en 1938 a la edad de 80 años, de quien se dice que fue el más destacado abogado que hubo entre los judíos de Salónica, indicando con su grafía cuál era la pronunciación del apellido familiar; y asimismo en la versión hebrea de dicho artículo (pág. 132) se publica una foto con los miembros del comité de la sociedad Matanot laEbyonim y entre ellos y en el pie de foto en letras latinas figura un «Itshac Chalem».

${ }^{6}$ Ángel Pulido Fernández, Españoles sin patria y la raza sefardí (Madrid: Tip. E. Teodoro, 1905) pág. 444.
} 
nica. Ignoro a qué «estimables composiciones» se refería Pulido, quien incluye además una fotografía de nuestro poeta, diferente de la que menciono más abajo, cuyo pie, como vemos, reza: «Fig. 132.- D. Salomón Salem, poeta y literato (Salónica)».

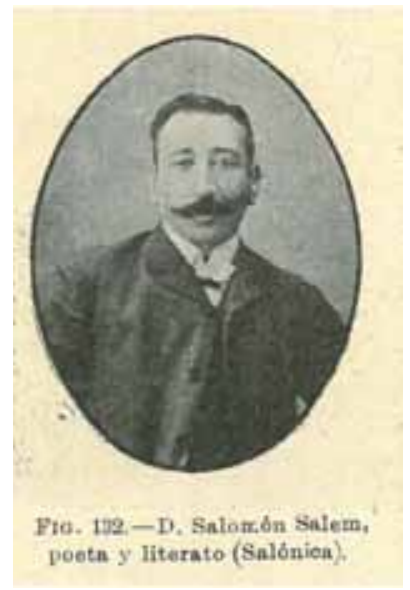

Pero curiosidades aparte y amén de las breves palabras que le dedica Nehama, diciendo que «Salomon Salem qui fut le meilleur poète judéoespagnol que Salonique ait jamais produit» ${ }^{7}$, el primer y casi único estudioso de nuestros días que se ha ocupado de la figura de Šelomó Ḥananiá Šalem ha sido Moshe Attias, quien en su artículo a él dedicado nos aporta algunos datos biográficos ${ }^{8}$, que he podido ampliar con otros nuevos, y edita, en transcripción a letras latinas y enfrentados a su traducción al hebreo, nueve de sus poemas?.

Nuestro autor nació en Salónica y, por lo que digo después, ello sería hacia 1873 o 1875 . Pertenecía a una de las ramas de la familia Šalem, muy conocida en la ciudad, y quizá fuera hijo o sobrino del Šelomó Šalem (1843-1904) que menciona Joseph Nehama ${ }^{10}$. Hizo sus primeros

\footnotetext{
${ }^{7}$ Joseph Nehama, Histoire des Israélite de Salonique, vols. VI y VII (Thessalonique: Communauté Israélite, 1978) pág. 756.

${ }^{8}$ Moshe Attias, «Šelomó H. Šalem - avir hamešorerim beladino», en Zijrón Saloniqui ..., redactor David A. RecAnAti (Tel Aviv 1986) vol. II, págs. 322-336.

9 En Attias, «Šelomó H. Šalem», págs. 327-334.

${ }^{10}$ En Histoire, pág. 665; vid. también pág. 732.
} 
estudios en el Talmud Torá, estudios que completó en la Escuela local de la Alianza Israelita Universal, paso habitual, según nos dice Nehama ${ }^{11}$, de los mejores alumnos del Talmud Torá.

Durante un tiempo y como mencionaba Pulido, trabajó como empleado de la Compañía de Aguas de la ciudad, trabajo que dejó en 1905 para abrir un comercio de mercería, negocio que no tuvo éxito, pasando dos años después a dedicarse a la carpintería y a la venta de muebles. Según menciona Attias ${ }^{12}$, en un artículo en La Época (32:1598: 23 tamuź 5667 / 5 lulio 1907), que he podido ver gracias a Dov Cohen, anunciaba la apertura de su empresa; y tiempo después organizó el sindicato de carpinteros de la ciudad. Los últimos años de su vida era dueño del Café Cristal.

He aquí el anuncio mencionado que aparece bajo el epígrafe «Aviśo» y firmado Šelomó Hananiá Šalem:

Sabiendo que esto hará plaćer a mis amigos, vengo aviśarles que vengo de abrir un atelier de menueśería ande se frabrica todo modo de moḅilia que rivaliźa con aquea faḅricada en los más grandes magaćines, sea como soliditá, sea como eleganza.

No es esto solo; hay la cuestión la más importante, aquea del precio que desfía toda conquerencia.

Vis̀itad todos los atelieres y después venid a mi atelier situado a la Carnicería Vieja, enfrente los šim 'onim ${ }^{13}$.

Los patrones de muevas construcciones tomen buena nota de este aviśo y no regretarán de haber tomado mis precios sobre todo artículo de duramá.

Que en 1900 era ya empleado en la citada Compañía de Aguas de Salónica lo confirma, por ejemplo, la siguiente breve nota aparecida en La Época (25:1246: 9 tamuź 5660 / 6 lulio 1900, pág. 10a):

Novedades locales.- [...] Muestro amigo y colaborador (SS) Se' Šelomó Šalem, de la Compañía de las Aguas, parte hoy por Tesalia por

\footnotetext{
${ }^{11}$ En Histoire, pág. 650.

${ }^{12}$ En «Šelomó Ḥ. Šalem», pág. 326, nota 5.

${ }^{13}$ Escrito שמעונים>sm 'wnym>, que no sé lo que es y en consecuencia tampoco estoy segura de haber leído bien la palabra. Por la terminación en -im del plural en hebreo, podría aventurar, pero sin ninguna seguridad, que se tratara de un comercio cuyos propietarios se llamaran Simón (hb. Šim ‘ón), lo que equivaldría a decir «la tienda de los Simones».
} 
hechos de familla. Sobre muestra rogativa, Se' Šalem quis̀o achetar a cargarse a mirar los intereses de La Época en Tesalia.

Muestro amigos y aḅonados son rogados, dunque, de facilitar la misión que Se' SS quis̀o graciośamente achetar.

Su no mucho cariño por la citada Compañía nos lo manifiesta el propio autor en su frase «me plaće mucho la compañía - no de las Aguas-» que podemos leer en el texto núm. 4 infra.

Su aborrecimiento por el trabajo de empleado y su deseo de abrirse camino en actividades independientes, lo que le llevaría a abrir las empresas mencionadas, queda claramente plasmado en el siguiente poema que apareció en su recopilación de poesías titulada La gavilla (págs. 31-32) -de la que me ocupo luego-, bajo el título Un empiegado, y que según Attias ${ }^{14}$ vio también la luz en La Época el 22 de febrero de 1901, versión que no he podido consultar. El poema está formado por 36 versos, agrupados en pareados; numero los versos de cinco en cinco y también son mías las separaciones entre bloques de versos (los títulos siempre son míos):

\section{Las desventuras de los empleados}

1 Yo creyo el hombre el más deśgraciado el que haće el mozo o el empiegado, miśmo que él tiene mestro o diretor o que barre gruta o que es controlor.

5 Su vida entera pasa en penserios y no son futiles, ellos son muy serios. Remarcad por cuálo yo vos digo esto, caeréš al cuento ${ }^{15}$ mucho mucho presto.

La mañana el mestro no te da bon jorno;

10 cuando él te habla, abre un bochorno ${ }^{16}$. Si tú lo acercas por hablar de hecho, te mira con ojo lleno de sospecho;

\footnotetext{
${ }^{14}$ En «Šelomó H.. Šalem», pág. 334, núm. 27.

${ }^{15}$ Es decir, caeréis en la cuenta, os daréis cuenta.

${ }^{16}$ Así escrito, pero debemos poner la expresión en relación con la que recoge Joseph Nehama en su Dictionnaire du Judéo-espagnol (Madrid: CSIC, 1977) s.v. bočórro, de «avrir bočorro» 'déverser un torrent de reproches, proférer des cris, des injures', es decir, 'abroncar'.
} 
y si te responde, todo con agrura ${ }^{17}$; ipor el empiegado cuanta amargura $i^{18}$.

15 Él, por iñoranza, comete un yero, a ti te lo pasa; cale mašques fiero ${ }^{19}$. Lo que es más negro y una manćía: cuando se pelea por la fantaśía ${ }^{20}$, no cale demandes nunca explicación,

20 porque te ataca de in-su-ḅor-di-na-ción ${ }^{21}$.

Por haćerte figas ${ }^{22}$ no te da meśada, no puedes pagarte ni una vaśada ${ }^{23}$; y si te la da, es al diez o al doĉe ${ }^{24}$, estonces mercarás el peje de hoche ${ }^{25}$,

25 siendo el pešcador no te da fiado; cuanto a los otros, mejor es callado ${ }^{26}$. A los creditores cale menajarlos, a tener pacencia cale engajarlos ${ }^{27}$. Viene con aranco el capo de año,

30 mestro y diretor les toma el daño ${ }^{28}$; por contentar solo el capricho suo,

\footnotetext{
${ }^{17}$ Es decir, la respuesta es siempre acre, con acritud.

${ }^{18}$ La admiración cerrada está en el original.

${ }^{19}$ Es decir, si el necio del jefe se confunde, le echa la culpa («lo pasa») al empleado, quien no tiene más remedio que morderse la lengua para no contestar; vid. NEHAMA, Dictionnaire, s.v. fyérro.

${ }^{20}$ Quizá se refiera a cuando el jefe se enfada por un problema que no existe.

${ }^{21}$ La palabra así separada en el texto mediante guiones.

${ }^{22}$ Es decir, para provocarte, para humillarte; vid. NeHAMA, Dictionnaire, s.v. fígas.

${ }^{23}$ El pobre empleado no puede darse el gusto de tomarse ni una copa.

${ }^{24}$ Es decir, bien entrado el mes siguiente.

${ }^{25}$ Escrito "חוג, es decir, con un pagaré (cf. tc. hüccet 'pagaré'); vid. tb. NeHAMA,
} Dictionnaire, s.v. joğét. No lo acentúo hoché por mor de la rima.

${ }^{26}$ Lo que prefiere callarse, pueden ser dos cosas: cómo se las arregla el pobre empleado para comprar otras vituallas, o cuáles son las otras muchas humillaciones que sufre por parte de su patrón.

${ }^{27}$ Es decir, a los que debe acostumbrar a tener paciencia es a aquellos a los que debe dinero (creditores), ya que siempre se retrasa en sus pagos.

${ }^{28}$ Nehama, Dictionnaire, s.v. daño recoge la expresión «tomar el daño kon uno» que explica «en avoir contre quelqu'un, lui manifester de l'antipathie, le prendre en grippe». 
te dejan otra vez en el «estatu cuo» ${ }^{29}$.

¡Beato quien tiene botica y gruta!, nunca él no pasa esta vida bruta;

35 y aquel que tiene y llave de buró ${ }^{30}$ el refrán dijo: «Su madre no lo lloró» ${ }^{31}$.

Según Attias ${ }^{32}$, Šalem comenzó a colaborar en La Época ${ }^{33}$ en 1899, colaboración que se prolongó durante doce años, lo que no entiendo demasiado, porque de ser cierto habría colaborado con el periódico hasta 1911, cuando -según veremos luego- Šalem murió en octubre de 1910. A principios de 1903 fue nombrado redactor responsable del suplemento La Época Literaria, que desapareció algún tiempo después, para volver a salir en mayo de 1908; a partir de esa fecha y según Attias ${ }^{34}$, Šalem fue un mero colaborador.

\subsection{Su fallecimiento}

Nos dice Attias $^{35}$ que Šalem murió repentinamente en Salónica -quizá de un infarto: un dolor repentino en el pecho que le produjo la muerte en unos minutos- el primer día de Sukot de 5671 (= 18 de octubre de 1910) cuando tenía 35 o 37 años. Ello me hace suponer lo que he anticipado arriba: que habría nacido hacia 1873 o 1875.

\footnotetext{
${ }^{29}$ La pleca que sigue está en el original.

${ }^{30}$ Es decir, el que maneja las finanzas, el que es propietario de un negocio.

${ }^{31}$ Es decir, que va a tener una larga vida y su madre no va a tener que llorar su muerte:
} vid. en Nehama Dictionnaire, s.v. mádre la expresión «kyen se gwadró [se akavidó], su madre no lo yoró».

32 En «Š́elomó H. Šalem», pág. 323.

${ }^{33}$ No parece necesario repetir aquí la historia del periódico; vid. al respecto los datos que anota Moshe David GaOn, A Bibliography of the Judeo-Spanish (Ladino) Press (Tel Aviv 1965 [en hebreo]) núm. 20. De las circunstancias que acompañaron a su fundación me he ocupado yo misma en Elena ROMERo, «La prensa judeoespañola contra los recelos, la burocracia y la censura», en Ayer y hoy de la prensa en judeoespañol, eds. Pablo MARTíN Asuero y Karen Gerson SARHon (Estambul: Isis, 2007) págs. 9-35: 17-26.

${ }^{34}$ En «Šelomó H. Šalem», pág. 325 y nota 17.

35 En «Šelomó H. Šalem», pág. 326 y nota 7. 
Sin embargo, los datos sobre su edad no dejan de ser un tanto confusos. En uno de sus poemas, Novios a la rifa, que publico más abajo (texto núm. 3, v. 37), aparecido en 1900, nos dice que en esa fecha tenía 30 años, lo que retrasaría su nacimiento a 1870; pero en otro texto que luego veremos (texto núm. 4), publicado en 1901 y donde él mismo hace su retrato, al hablar de su edad dice: «tengo mis vente y ocho (2) cumplidos», aclarándose en nota 2: «Sin contar las noches», lo que -gracieta aparte con lo de las noches- supondría que habría nacido en 1873; y tal edad de Šalem es la que, también en 1901, le adjudica Alberto Taragano (texto núm. 5 infra, vs. 14-15): «Y SS con sus vente y ocho / está alegre y venturośo».

Según nos dice Attias ${ }^{36}$, pocos días después de su muerte, el 21 de octubre, el redactor del periódico, Šemuel Sa'adi Haleví, publicaba en La Época un artículo en su memoria, que he podido consultar gracias al texto remitido por Dov Cohen. Y esto es lo que leemos en La Época 2517 (18 tišrí 5671 / 21 octubre 1910, pág. 1a-b), firmado por Šemuel Sa'adi Haleví. El artículo va precedido de una fotografía de Šalem, igual a la que aparece en La gavilla, a la que sigue el epígrafe centrado: «Šelomó H. Šalem».

Mi ojo lagrimea, la mano me tembla en tomando la péndola para escribir la necrología de un amigo querido, de un colaḅorador fiel, como fue para nośotros Šelomó Hananiá Šalem (SS).

La muerte de Šelomó Šalem non llaga solo su familla, no aharba solo La Época, ma ella alcanza también la comunidad judía de Salonico, ella marca sobre todo una piédrita para el judeo-español.

Los póberos parientes del caro desparecido lloran y llorarán al sostenedor, a la esperanza de la caśa ande no habrá más por endelantre quien que ría, quien que hable, quien que se alegre. La lágrima será el solo consuelo y la adefla quedará para siempre enfincada en sus corazón.

La Época tuvo siempre en Šelomó Šalem un amigo sincero. Cuando los amigos de ayer se haćían güercos al otro día, cuando el viento del celo y de la envidia pujaba miśmo aqueos que el día de antes habían sido muestros obligados, nuestros devdores, Šelomó Šalem, que conocía todo y a cada uno, se tenía a nuestro lado, contente de recibir los golpes, si ellos debrían luviar.

La comunidad judía piedre un nacionalista que no heśitaba a reśicar su pan, a exponer su vida por no deǰar areḅaǰar el nombre de jidió. La firmeza

\footnotetext{
${ }^{36}$ En «Šelomó Ḥ. Šalem», pág. 326 y nota 7.
} 
de este mancebo dio mucho a pensar a los mancebos que eran un tiempo indiferentes y hoy se duelen por su ${ }^{37}$ jidió. El regretado difunto fue uno de los acimentadores del nacionaliśmo jidió en Salonico.

Para mostrar cómo el pueblo debe llorar a Šelomó Šalem yo dejo por un punto revenir mi penserio sobre doĉe o treĉe años atrás y veo Šelomó Šalem venir a la estampa con un cuadreno [sic] de notas a la haldiquera. Estas notas eran los elementos de aqueos artícolos firmados «Campo Liḅre» que hićieron una verdadera revolución en nuestra comunidad a la cuala rindieron servicios enormes.

De ahí data la primera centea de nacionaliśmo; de ahí la mancebez judía empezó a tomar concencia de sí y un aure de organización empezó a soplar, o deśeo de grupamiento empezó a manifestarse.

Como se uśaba bajo el viejo reǵim ${ }^{38}$, la paga de aqueos esforzos fue dada en contante. Šelomó Šalem fue obligado de empeñarse por pagar todo el niźam bedelí, tị̂aret y yol parasí ${ }^{39}$ que le reclamaban, y poco mancó que yo me fuera haćer ocho días de priśión, que iban ser los más gloriośos de mi vida.

Tengo raźón de dećir que todos tienen obligo de llorar a Šelomó Šalem. Ma este obligo, estos lloros, ¿qué pueden haćer para aquel deśgraciado que se fue a la flor del yivir, lleno de vidas y de salud, vencido por una simple dolor de boca de alma ${ }^{40}$, un gómito que turaron en todo cinco puntos...?

¡Póbero, póbero Šelomó!, tú que hićítes tanto por los otros, tú que te sostuvites tanto en el pleito que librimos porque nuestros muertos fueran llevados adientro de caros fúnebres, tú fuites arancado tan brutalmente a la vida en manco de nada, en abrir y cerar el ojo.

\footnotetext{
${ }^{37}$ Quizá se trate de una errata por ser.

${ }^{38}$ Alude a los tiempos del gobierno de los sultanes; recordemos que para estas fechas Abdul Hamid II, al que puede considerarse el último sultán, ya había sido depuesto.

${ }^{39}$ Nombres de tres impuestos que, al parecer, dejaron a Šalem en la ruina. Puedo identificar el llamado niźam bedelí (tc. nizam bedeli) de exención del servicio militar, al que tenían derecho las minorías del Imperio otomano -vid. Elena Romero, Entre dos (o más) fuegos. Fuentes poéticas para la historia de los sefardíes de los Balcanes (Madrid: CSIC, 2008) cap. 10, págs. 482-488-, y quizá el llamado tijaret (tc. ticaret 'comercio') se trate de un tipo de impuestos sobre actividades comerciales. Sin embargo, no tengo claro a qué se refiere el yol parasí; cf. tc. yol 'camino, calle', 'ley', 'viaje', y parasí (tc. para lit. 'su dinero') 'dinero, moneda'. Sobre el régimen impositivo, puede verse Nehama, Histoire, vol. VI, cap. IV y vol. VII, págs. 539-540.

${ }^{40}$ Es decir, la boca del estómago, el epigastrio; vid. NeHAMA, Dictionnaire, s.v. bóka.
} 
Y en manco de nada, en abrir y cerar el ojo pocas horas después de haber dado el último reflo, pocas horas después de haber cativado tus oidores con tu habla irónica y tus yierbos por reír, tú te ibas adientro cuatro tablas enclavadas, bailando entre los brazos de seš bravos hombres para la más deśolada morada de siempre, para el más triste cemeterio que el hombre que pensa puede imaǵinar.

¡Póbero, póbero poeta!, ¿quién te había de dećir que tu fin iba a ser tan triste, tan supitaña ${ }^{41}$ ?, ¿quién te había de dećir que tu acompañamiento sería tan precipitado, tan no sé cuálo? ¡Ansí va el mundo!, dećía J́ac Danón ${ }^{42}$, otro un ferviente admirador de Šelomó Šalem; ansí te fuites tú, caro amigo, haćiendo el más grande buraco en el corazón de toda tu ĝente, en el corazón de todos tus amigos, dejando un grande vaćío entre los capitanes de la armada nacionalista judía que va apreciar tu valor en viendo tu faltida.

¡Durme amigo!, ¡durme del sueño eternel! Si tal es que la alma de los muertos viene en većes sobre la tiera, yo rogo que la tuya pase frecuentamente por Salonico para que ella anime al sentimiento de tus coreligionarios y les diga al oyido, al corazón, que el hombre se va como vino; lo que queda son solo las buenas obras, es solo el buen nombre. ¡El tuyo va quedar, amigo!...

Parece que Šalem había tenido una cierta premonición acerca de que Haleví habría de escribir su elogio fúnebre, ya que tal es lo que dice en su poema titulado Ya se lo llevan, aludiendo a que se lo llevan a enterrar, que apareció en La gavilla (págs. 25-26) -versión en la que me baso- y que también se publicó en La Época el 25 de enero de $1901^{43}$, versión que no he podido consultar.

El poema, a dos columnas, consta de 82 aleluyas, separadas en la pág. 25 de La gavilla como si fueran cuartetas, pero sin separaciones en la página siguiente. Presento el texto todo él seguido, numerando los versos de cinco en cinco, y, salvo la última, son mías las separaciones entre bloques de versos.

\footnotetext{
${ }^{41}$ Habríamos esperado supitaño.

${ }^{42}$ Se refiere a Jacques Danón, rabino y erudito sefardí, que fue miembro correspondiente de la Real Academia de la Lengua Española. A él se debe la fundación del Seminario Rabínico, sito primero en Adrianópolis y más tarde en Constantinopla, que funcionó hasta su emigración a París en 1917. Sobre él puede verse la bibliografía que recojo en Romero, Entre dos (o más) fuegos, cap. 8, nota 59, y «La polémica sobre el judeoespañol en la prensa sefardí del Imperio otomano: Más materiales para su estudio», Sefarad 70:2 (jul.-dic. 2010) págs. 435-473: 448, nota 17.

${ }^{43}$ Según AtтiAs, «Šelomó Ḥ. Šalem», pág. 334, núm. 24.
} 


\section{Elogios al muerto que está vivo}

1 Quinće días en la cama, pronto para dar el alma, no vino ni mi većino demandar por el haćino.

5 Los amigos de el vaśo ${ }^{44}$ y los de cuatro a aśo ${ }^{45}$, en estando en ajunta ${ }^{46}$, no mandaron ni pregunta. Y los otros caronales,

10 en supiendo los mis males, me creeron condanado, no vinieron por a' lado $^{47}$. Se dijeron: «A la muerte -la creeron ya enfrente

15 esta ĝente hipocrita- ${ }^{48}$ haćemos una vis̀ita» ${ }^{49}$. De todos los mis colegas, -¡así buena salud tengas!-, de trenta me vino uno,

20 no lo digas a ninguno. Y muestro capo redactor, ya lo conoces tú, lector, empezó, ¡así yiva él!, para el día solanel

25 a haćer discurso pronto, ¡como fuese ${ }^{50}$ yo un tonto de morirme en invierno y sin ser aínda yerno!... ${ }^{51}$.

Ma gracias a Naḥum doctor,

\footnotetext{
${ }^{44}$ Es decir, los amigos con los que se reunía para tomarse unas copas.

${ }^{45}$ Escrito אזו 'as'; vid. Nehama, Dictionnaire, s.v. ázo. Debe estar aludiendo a un juego de cartas o de dados.

${ }^{46}$ Es decir, juntos, quizá jugando la partida habitual.

${ }^{47}$ Es decir, no se acercaron a visitarle.

${ }^{48}$ Los guiones están en el texto.

${ }^{49}$ Es decir, cuando se muera, irán a hacer una visita para dar el pésame a la familia.

${ }^{50}$ Habríamos esperado: «como si fuese».

${ }^{51}$ La admiración final y los puntos suspensivos están en el texto.
} 
30 que de cencias es amator, y Gateño, el dantista ${ }^{52}$, que los dos a prima vista, con que tiempo no les sobra, se metieron a la obra

35 y dientro de cuatro días yo uśí de mis rodías.

Uno a dos días después yo me metí sobre mis pies y me fui a la redacción

40 con una negra inteción a demandar por Šemuel ${ }^{53}$.

Súpito veo un papel el arés ${ }^{54}$ todo de preto. ¿Saber queres el secreto? ${ }^{55}$

45 ¡Oh!, esto es mucho fuerte: el discurso de mi muerte. Heg cómo empezaba, ya sabéš su elocuenza:

«Es con una dolor imensa

50 y con temblor en los niervos que hoy digo dos tres yierbos por el querido difunto que mos plonj́o en el luito. Él era un pamfletario...

55 y también pleḅicitario... ¡Era lleno de esprito!, ¡que lo toparéš escrito en el libro de el sabio!... ¡Nunca no tuvo agravio!...

60 Tuvo tantas cualidades:

\footnotetext{
${ }^{52}$ Vuelve a referirse a este dentista en el texto núm. 4 infra. No he podido encontrar datos sobre ninguno de los dos médicos citados.

${ }^{53}$ Se refiere a Šemuel Sa 'adi Haleví.

אריס; vid. Nerito victionnaire, s.v. arrés. Es decir, con los bordes negros (preto).

${ }^{55}$ La interrogación final y la admiración final que sigue están en el texto.

${ }^{56}$ Estos puntos suspensivos y todos los que siguen están en el texto, así como las admiraciones finales.
} 
escribió "Las dos edades",

les echó buenas ventośas

"A las hij́as vanitośas".

El torno no ha venido

65 de hablar "Del parvenido"

y del hombre orgullośo

y del tipo misteriośo.

Como estos otros vente

¡y que no escruja diente!

70 Llorad, alguayad, parientes;

vuestros ojos haćed fuentes

por esta preciada joya

que hoy meten en la foya.

¡A Ạ!, ¡cielo, cielo!

75 como el hombre modelo... ${ }^{58} \gg$.

Después me fue imposible,

siendo era ileǵible,

continuar la lectura.

Si va tener la ventura

80 pueder dečifrar el resto

lo sabrás y mucho presto.

En los vs. 61-67 se está aludiendo a varios poemas de Šalem publicados en LaÉpoca, cuyos títulos-unos entrecomillados y otros no-, no corresponden siempre a los que llevaban cuando se publicaron, lo que induce a pensar que Haleví estaba citando de memoria. Son los siguientes: «Las dos edades», titulado Un hombre entre las dos edades en La Época (9 nov. 1900) ${ }^{59}$; «A las hijas vanitośas», que apareció con el título de Una hija vanitośa en La Época (7 oct. 1900) y en La gavilla (págs. 19-22) ${ }^{60}$; «Del parvenido», cuyo título es Un parvenido en La Época (14 oct. 1900) y en La gavilla (pág. 19) ${ }^{61}$ y que yo misma he editado con el título de Un advenedizo ${ }^{62}$;

${ }^{57}$ Estas comillas y las que siguen están en el texto.

${ }^{58}$ La separación que sigue está en el texto.

${ }^{59}$ Vid. AtтiAs, «Šelomó Ḥ. Šalem», pág. 334, núm. 20.

${ }^{60}$ AtтiAs, «Šelomó Ḥ. Šalem», pág. 334, núm. 12.

${ }^{61}$ AtтiAs, «Šelomó Ḥ. Šalem», pág. 334, núm. 13.

${ }^{62}$ En Elena Romero, «Poetas sefardíes en la Salónica de 1900: ¿un ajuste de cuentas?», Hesperia 5:6 (2009) págs. 107-126, núm. 1. 
«Del hombre orgullośo», titulado Un orgulloso en La Época (28 oct. 1900), trascrito por Attias ${ }^{63}$; y «Del tipo misteriośo», titulado Un misteriośo en La Época (28 dic. 1900) y en La gavilla (pág. 24) ${ }^{64}$.

Su muerte tuvo también repercusión en otros periódicos de Salónica, dato que conozco gracias a los textos que me ha remitido Dov Cohen. Esto es lo que leemos en El Avenir 13:103 (25 tišrí 5671 / 28 octubre 1910):

El primer día de Sukot murió súbitamente en una edad prematura el bien conocido Šelomó Šalem, patrón del Café Cristal. El difunto era universalmente estimado y amado por su natura luayala, alegre, plaćentero y caridable. Él tuvo escrito hermośas poeśías y sea en ellas como en sus actos se manifestaba un sincero amor nacional. Él tomó una ancha parte en la creación del Aśilo de $\operatorname{Locos}^{65}$ y en muchas otras obras de bien. Preśentamos a la famía en luito nuestras sinceras condolienzas y rogamos porque la alma del difunto repośe en paz.

Y asimismo en El Imparcial (17 tišrí / 20 octuḅre 1910) leemos:

Enreǵistramos con un ỵivo regreto la muerte de Se" Šelomó Šalem, director del Café Cristal, arebatado a la vida día de martes, por un golpe de apoplexía. El difunto, poeta de talento y hablador muy agradable, tenía muchos amigos. También una asistencia muy numerośa se hiźo un dober de acompañarlo a su última morada. A la familla en luito adrezamos muestras sinceras condolienzas.

Y en el mismo número de La Época antes citado (2517, 18 tišrí 5671 / 21 octuḅre 1910, pág. 1c) se describe su funeral:

Los funerales de Šelomó Šalem fueron muy impośantes. Delantre milarias de pueblo muestro redactor en capo adrezó al muy regretado amigo un último adío que hiźo verte[r] lágrimas aḅundantes.

\footnotetext{
${ }^{63}$ En «Šelomó Ḥ. Šalem», págs. 329-330, núm. 15.

${ }^{64}$ AtтiAs, «Šelomó Ḥ. Šalem», pág. 334, núm. 21.

${ }^{65}$ Sobre esta institución, fundada en 1908, pueden verse las líneas que le dedica Alfonso LEvI, «Haquehilá veišeah bašanim haḥaronim», en Zijrón Saloniqui ..., redactor David A. Recanati (Tel Aviv 1986) vol. II, págs. 149-167 (resumen en judeoespañol en letras latinas: «La communita mientres los últimos anios», en pág. 23): pág. 156, y también Michael MolHo, «Hašejunot hayehudiyot beSaloniqui», en Zijrón Saloniqui ..., redactor David A. Recanati (Tel Aviv 1986) vol. II, págs. 5-31 (resumen en judeoespañol en letras latinas: «Los Faubourgos de Salonique a traverso los siecolos», en págs. 9-11): pág. 20.
} 
Los miembros del Cluḅ deś Intime llevando el manto, miembros del Nuevo Club ${ }^{66}$, dos centros de los cualos haćía parte Šelomó Šalem, y mucha mancebez judía acompañaron hasta su última morada el mancebo que difícilmente se puedrá olvidar.

Que el Todo Potente mande afalago a su[s] parientes amargos y a todos los que lo lloran. Tnŝbh ${ }^{67}$.

\subsection{Variedad de su producción literaria}

Se ocupa asimismo Attias ${ }^{68}$ de la variedad de su producción literaria, tanto en prosa como en verso: artículos periodísticos, colecciones de refranes $^{69}$, adivinanzas, novelas traducidas del francés, una versión de la Ester de Racine ${ }^{70}$, y adaptaciones de las fábulas de La Fontaine y de Félix María de Samaniego.

De estas fábulas recoge Attias ${ }^{71}$ una lista de 36, publicadas en $L a$ Época entre el 15 de noviembre de 1901 y el cinco de julio de 1908 . Y por su parte Michael Molho ${ }^{72}$ transcribe dos: El lovo y el codrero-que no aparece con tal nombre en la lista de Attias- y La cigala y la hormiga $^{73}$.

${ }^{66}$ Se refiere a dos de los clubes de intelectuales más activos de Salónica. Para el primero vid., por ejemplo, Elena ROMERo, Repertorio de noticias sobre el mundo teatral de los sefardíes orientales (Madrid: CSIC, 1983) Índices, s.vv. Club y Comité, y Nehama, Histoire, págs. 713 y 731; y para el segundo, Romero, Repertorio, Índices, s.v. Muevo Club.

${ }^{67}$ Escrito תנצבה, abreviación de hb. תהי נפשו צרורה בצרור החיים Tehí nafšó serurá biŝseror hahayim ('Sea su alma conservada en el haz de la vida'), fórmula que forma parte del ritual mortuorio judío.

${ }^{68}$ En «Š́elomó Ḥ. Šalem», págs. 324-325.

${ }^{69}$ AtтiAs, «Šelomó Ḥ. Šalem», pág. 324 y nota 9.

${ }^{70}$ AtтIAS, «Šelomó H. Šalem», pág. 325, según figura en un artículo publicado en $L a$ Época el 20 de enero de 1905, versión de la que no me ha llegado otra noticia. Dice Attias que en dicho artículo el director del periódico promete publicar el texto por entregas en La Época y procurar que fuera representada.

${ }^{71}$ AtтiAs, «Šelomó Ḥ. Šalem», págs. 335-336.

${ }^{72}$ En Literatura sefardita de Oriente (Madrid - Barcelona: CSIC, 1960) págs. 312314, núms. 4-5.

${ }^{73}$ AtтiAs, «Šelomó Ḥ. Šalem», núm. 3. 
Al respecto de este último texto nos dice Saporta ${ }^{74}$ que en una fiesta organizada por el Liceo Francés de la ciudad en el Teatro del Parc -por desgracia, Saporta no da fecha- un niño recitó en francés dicha fábula a lo que siguió otro niño recitando la versión de Šalem en judeoespañol, que Saporta publica ${ }^{75}$. Tras la salva de aplausos que siguió a su actuación, el niño volvió a la escena y dijo ${ }^{76}$ : «Esta fábula de La Fontaine que acabo de dećirvos en judeśmo ha sido tradućida por el siñor Salamó Salem», a lo que siguió otro trueno de plausos.

Como ejemplo de sus adaptaciones de fábulas transcribo a continuación la siguiente, que apareció en La Época 31:1583 (29 adar 5667 / 15 marzo 1907, pág. 4a) ${ }^{77}$ y que viene precedida del siguiente comentario:

Nuestro colaborador SS nos emvía la poeśía sigüente del poeta español D. Félix María Samaniego, de Madrid, escrita en español puro y que reproduićimos a la letra ${ }^{78}$. SS quis̀o bien a su torno redijarla en nuestro idioma judeo-español y darle la sabor que plaće a nuestros lectores. Publicamos, dunque, las dos poeśías tuviendo el miśmo sujeto, ma de autores diferentes para que se pueda apartar la diferencia entre la lingua española y el jargón judío-español.

En el cuadro que sigue presento a la izquierda el texto de Samaniego según una edición publicada en Barcelona en $1844^{79}$; y a la derecha la versión que apareció en La Época en letras latinas. En ambos casos lo reproduzco tal y como está escrito:

\footnotetext{
${ }^{74}$ Enrique SAPORTA y BeJA, En torno de la Torre Blanca (Paris: Vidas Largas, 1982) págs. 244-247.

${ }^{75}$ SAPorta y Beja, En torno de la Torre Blanca, págs. 246-247.

${ }^{76}$ Los textos que reproduzco de la citada obra de Saporta los paso siempre a mi sistema de transcripción, aunque respeto su vocalización.

${ }^{77}$ Vid. también AtтıAs, «Šelomó Ḥ. Šalem», pág. 336, núm. 31.

${ }^{78}$ Es decir, literalmente.

${ }^{79}$ Para la edición española manejo la que ofrece Google Books y que me ha proporcionado Aitor García Moreno, a partir, según reza el ex libris, del ejemplar de la Biblioteca Central, Diputación Provincial de Barcelona (sign. A-83-8-7346), cuya portada dice así: «Fábulas de Esopo, Phedro, Iriarte, y Samaniego, para el uso de las Escuelas Primarias. Nueva edición en un solo volumen. Barcelona, Imprenta y Librería Española y Estrangera [sic] de J. Roca y C. ${ }^{a}$, calle de Escudellers, n. ${ }^{\circ} 18,1844$ ». Nuestra fábula aparece en el Libro Quinto, Fábula VI (págs. 94-95).
} 


\begin{tabular}{|c|c|}
\hline Barcelona 1844 & La Época 1907 \\
\hline La Gallina de los huevos de Oro & La gallina de los huevos de oro \\
\hline $\begin{array}{l}\text { Erase una Gallina que ponia } \\
\text { Un huevo de oro al dueño cada dia. } \\
\text { Aun con tanta ganancia mal contento, } \\
\text { Quiso el rico avariento } \\
\text { Descubrir de una vez la mina de oro, } \\
\text { Y hallar en ménos [sic] tiempo mas tesoro. } \\
\text { Matóla, abrióla el vientre de contado. } \\
\text { Pero después de haberla registrado, } \\
\text { ¿Qué sucedió? que muerta la Gallina, } \\
\text { Perdió su huevo de oro, y no halló mina. }\end{array}$ & $\begin{array}{l}\text { Erase una gallina que ponia } \\
\text { un huevo de oro al dueno cada dia; } \\
\text { aun con tanta ganancia, mal contente } \\
\text { quiso el rico avariento } \\
\text { descubrir de una vez la mina de oro, } \\
\text { y hallar en menos tiempo mas tesoro. } \\
\text { matola, abriola el vientre de contado; } \\
\text { pero despues de haberla registrado, } \\
\text { que sucedio? Que, muerta la gallina } \\
\text { perdio su huevo de oro y no hallo mina. }\end{array}$ \\
\hline $\begin{array}{l}\text { ¿Cuántos hay que teniendo lo bastante, } \\
\text { Enriquecerse quieren al instante, } \\
\text { Abrazando proyectos, } \\
\text { A veces de tan rápidos efectos, } \\
\text { Que solo en pocos meses, } \\
\text { Cuando se contemplan ya marqueses, } \\
\text { Contando sus millones, } \\
\text { Se vieron en la calle sin calzones! }\end{array}$ & $\begin{array}{l}\text { Moral } \\
\text { Quantos hay que, teniendo lo bastante, } \\
\text { enriquecerse quieren al instante, } \\
\text { abrazando proyectos } \\
\text { a veces de tan rapidas }[\mathrm{sic}] \text { efectos, } \\
\text { que solo en pocos meses, } \\
\text { quando se contemplaban ya marqueses } \\
\text { contando sus milliones [sic] } \\
\text { se vieron en la calle sin calzones. } \\
\text { D. Feliz Maria Samaniego }\end{array}$ \\
\hline
\end{tabular}

Obviamente no puedo saber de qué edición española se valiera Šalem para la reproducción en español de la fábula de Samaniego, pero, en cualquier caso no son muchas las diferencias entre ambas versiones. Y así encontramos diferente mayusculización y puntuación, ausencia de tildes en el texto salonicense -algunas de las cuales también están en la versión española que manejo (ponia, dia, así como ménos -bien escrito en la versión de La Época-, mas, etc.)-, y la grafía dueno para dueño, por la esperable ausencia del tipo de la eñe en las imprentas de Salónica. Son escasas las diferencias léxicas: contento / contente, cuántos / quantos, cuando / quando, contemplan / contemplaban y millones / milliones. Cabe señalar también la falta de concordancia en el texto de la Época en rapidas efectos. En la versión salonicense se separa mediante el epígrafe Moral el texto de la fábula de su moraleja, lo que en el texto español se resuelve escribiendo dicha moraleja en cursiva. Y asimismo en la versión de La Época se añade al final el nombre del autor. 
Sigue a continuación la versión de Šalem en aljamiado, que dice así:

\section{La gallina de los güevos de oro}

Quien quere y lo mucho, piedre y lo poco

todos lo saben afuera de el loco

y por convencervos acostad oreja

por que tiréš moral de esta conseja.

Un avaro tenía una gaína

que de güevos adientro tenía mina, siendo los que metía eran de oro. El avaro, pensando topar treśoro, a la pobre gainica la degolla.

Los niños de detrás ${ }^{80}$ le gritan ¡Oya! $!^{81} \ldots$ porque no topó que tripas y moleja. El loco vos emỵeźa esta conseja

\section{Moral}

Buena lición para hombres escarsos, que este ${ }^{82}$ tiempo se topan a mazos.

No bastándoles lo que tienen, lo suyo, bušcan ganar más, queren los superfluo ${ }^{83}$.

Laboran, afrontan toda dificultad;

cuando ya creen alcanzar sus veluntad, ven en súpito que viene sus robina, como aquel hombre de la gaína.

${ }^{80}$ Es decir, detrás de él.

${ }^{81}$ Escrito אוייה. Parece tratarse de un juego de palabras entre la exclamación óya que recoge Nehama, Dictionnaire, s.p.v., indicando que tiene un sentido de reprobación y de desprecio, y la palabra española olla, que recoge Nehama allí mismo, indicándole al avaro que la gallina degollada ya solo sirve para cocinarla y comérsela. Me lleva a creer que se trata de tal juego lo que dice el siguiente verso, que al iniciarse mediante porque parece estar explicando el sentido de lo que gritan los niños.

${ }^{82}$ Habríamos esperado «en este».

${ }^{83}$ Escrito סופיפ׳רלואו. 
Respecto a los refranes por él recogidos esto es lo que dice Moisés Abravanel en una carta a Ángel Pulido ${ }^{84}$ (mantengo la grafía del original):

Mi amigo Señor Salomon Salem, el qual me remete la tarjeta visita por Usted, me dicho que tiene una coleccion de proverbios y citaciones al numero de 1000, todos usados i empleados por las famillas Júdeo Españolas, si le son de utilidad me are un plaser a demandarlos por mandarlos a Usted.

Se me escapa que puedan ser las citaciones aludidas -quizá dichos o expresiones-, pero lo cierto es que resulta penoso que tal colección no llegara a manos de alguien interesado en su publicación y difusión en España.

\section{DATOS PERSONALES PROPORCIONADOS POR ÉL MISMO}

Aún podemos añadir a lo ya visto un par de textos en los que Šalem se describe a sí mismo.

Tal es el caso del poema titulado Novios a la rifa que apareció en La Época 25:1244 (25 siván 5660 / 22 junio 1900, pág. 4b) ${ }^{85}$ y que también se incluyó en La gavilla (págs. 16-18). En la versión del periódico el texto viene firmado al pie por la indicación de «Šaḅat Šalom» ${ }^{86}$ en letra raší y en cuerpo mayor las letras que marco en negrita, que también son las siglas del nombre de nuestro autor. Uso como base de mi edición la versión que se publicó en La Época y marco entre corchetes las variantes en La gavilla. En ambas versiones y tras el título leemos: «Hay un refrán que diće: "El Dio tiene cuidado [miśmo] de una hormiga, / siendo Él mantiene cienes con una sola miga"». El texto, organizado en pareados, consta de 40 versos en la versión de La Época, donde está presentado a dos columnas y todo seguido, salvo las dos plecas que indico luego, y de 42 en la de $L a$ gavilla, donde se añaden los vs. 21-22 de mi numeración.

\footnotetext{
${ }^{84}$ En Españoles sin patria, pág. 443.

${ }^{85}$ Vid. AtтıAs, «Šelomó Ḥ. Šalem», núm. 10.

${ }^{86}$ A este juego de palabras hecho por el propio autor con las siglas de su nombre y apellido es al que me refería en nota 5 supra, ya que la segunda palabra solo puede leerse como la transcribo.
} 


\section{Novios a la rifa}

1 Ma mośotros [nośotros], que solo el nombre es que se puede topar de hombre:

(no somos que animales [animal] salvaje, a dećirlo tengo el coraǵe) ${ }^{87}$,

5 mos debemos recíprocamente, por yivir en este continente, de el uno al otro ayudar, por el mancebo un poco cuidar. Cale tomar en consideración

10 a esta bendicha propośición que La Época quis̀o bien haćer.

Las niñas, sin se haćer beźer, de esta rifa tomen bilieto sin pensar que es David o Lieto ${ }^{88}$

15 que les puede reśervar el sorte. Que cada una se conhorte, siendo si no le plaće el novio, porque es blanco, preto o rubio [royo], refuśarlo tiene el dirito,

20 dejarlo amargo y afrito [tomar la mitad de la ganancia y aḅandonar toda la ansia] y [om. y] espośarse [espośándose] con su querido $\mathrm{y}$ al año haćerlo parido [y haćer de él un buen marido].

25 Por tomar parte a esta rifa, de mancebos hay grande estifa ${ }^{89}$; ma, tuviendo dirito de invanción, a proponerme tengo [la] inteción $\mathrm{y}$, sin formar dingún sindicato,

30 me propongo como candidato. Porque me conozcáš só costreto a [om. a] haćervos [haćer de mí] un chico portreto. 90

${ }^{87}$ En Gavilla los paréntesis se cambian en comillas.

${ }^{88}$ En Gavilla el nombre de Lieto entre comillas.

${ }^{89}$ Es decir, gran cantidad; $c f$. NeHAma, Dictionnaire, s.v. estífa.

${ }^{90}$ En Gavilla, en lugar de esta pleca, aparece una separación mayor. 
¿Hermośo? Mamá me tuvo dicho que yo só un mancebo bendicho.

35 ¿Talla?: un metro y noventa, todo lo que visto me asenta ${ }^{91}$. ¿Edad?: trenta diće mi famía, no creer es una infamía. ¿Profesión?: sin ser mucho rogado

40 vos digo que só un empiegado. ¿Fortuna?: mejor es amudición ${ }^{92}$, no demandéš por mi situación.

El poema no venía a humo de pajas, ya que, como he dicho en otras ocasiones $^{93}$, en números anteriores del periódico se habían publicado algunas colaboraciones en prosa y en verso sobre los problemas que tenían los jóvenes casaderos para recabar dotes que les permitieran, tras la boda, labrarse un futuro económico. En tales artículos se proponía organizar rifas de novios; el dinero obtenido serviría como dote, y, si la presunta novia renunciaba, se lo repartían entre ambos. Hay que entender, pues, este poema como un testimonio irónico de lo que estaba pasando en esos momentos en Salónica con los eternos problemas de las dotes. Por otra parte, según lo que Šalem dice en v. 27 -que él tiene «dirito de invanción»-, podríamos deducir que él ha sido el responsable de tan chusca idea.

Veamos ahora el segundo texto con su auto-descripción. En 1901 y como también ya he dicho ${ }^{94}$, el por entonces redactor del periódico y ya varias veces citado Šemuel Sa'adi Haleví, tuvo la idea de iniciar en $L a$ Época una serie titulada Retratos, en los cuales los colaboradores habituales del periódico se describían a sí mismos ante los lectores. Conozco

${ }^{91}$ Es decir, todo lo que se pone le sienta bien.

${ }^{92} \mathrm{Al}$ preferir callarse sobre su fortuna, el poeta está dejando entrever que no posee dinero.

${ }^{93}$ Vid. Elena Romero, «Tres mujeres colaboradoras del periódico de Salónica La Época, de 1900 a 1907», en Jewish Journalism and Press in the Ottoman Empire and Turkey, ed. Rifat N. BALI (Istanbul: Libra Kitap, 2016) págs. 231-263, apdo. 1.4, y RoMERo, «Mlle. Elisa: Una periodista sefardí colaboradora del periódico de Salónica $L a$ Época a principios del siglo XX», en Mujeres sefardíes lectoras y escritoras, siglos XIXXXI, eds. Paloma Diaz-Mas y Elisa Martín OrTega (Madrid: Iberoamericana - Vervuert, 2016) págs. 197-206, apdo. 2.

${ }^{94}$ En «Tres mujeres», apdo. 1. 
13 de tales Retratos cuyas firmas -generalmente con seudónimo- son de las que encontramos más veces repetidas en las páginas de La Época; por ejemplo: «Guśano de charší», Eliyahu Šem-Tob Arditi, D. Rogman, «Véritas», «Un Humano», Josef Romano, etcétera, etcétera.

Pues bien, el Retrato núm. 1 que inicia la serie apareció en La Época 26:1297 (viernes 25 tamuź 5661 / 12 lulio 1901, pág. 7b-c) y lo firma precisamente SS, es decir, nuestro Šelomó Šalem. Esto es lo que nos dice:

\section{Retratos $(1)^{95} 1$}

A la demanda biscornuda ${ }^{96}$ hecha de parte la redacción de el jurnal $L a$ Época, yo respondo con la demanda sigüente. ¿Ex́iste cośa más difícil en el mundo que de querer pintarse si miśmo?

Si digo difícil, se entiende bien que non lo digo por mí, siendo todos los meldadores de el jurnal La Época me conocen muy bien por haber visto mi portreto y por haber meldado algunos de mis escritos. Non tengo que a meter SS deḅajo de sus ojos por que ellos se metan a sus torno a haćer mi portreto, iy qué portreto...!

Cuanto a aquellos que non me conocen (y ellos deben ser raros), con las pocas líneas que sigüen puedrán y ellos conocerme.

¡Atanción..., yo empezo! der.

¿Inteliǵenza...? ¡Hum...! Na la dificultad. Te deǰo a ti, lector, respon-

¿Edad...? El coraǵe me manca... Si..., no... Vo la descubriré, si me prometéš el secreto (¡amigos, piadad!): tengo mis vente y ocho (2) cumplidos.

¿Hermośo? Ya vos tuve dicho que mamá me diće que só un mancebo bendicho.

¿Talla? Más ariba de la mediana. ¿Mi cabeo? Preto era en primero. Frente alta. Más presto llamad oreja (3) lo que tengo y non oído. Ojo que deśea ver todo lo bueno. Nariz proporcionada. Enṿidian muchos mis mostachos, ma muy pocos mi pośición. Boca, non siendo ni chica ni grande, diće a las većes cośas que pasan por grandes. Dientes, gracias a Gateño mašcan leño. Eluenga blanda, ma muchas većes puncha.

${ }^{95}$ Estos números entre paréntesis, de los que hay tres, corresponden a sendas notas cuyos textos figuran al pie del texto y que se supone, según se dice en la nota 1, que son comentarios de la redacción del periódico. Recojo tales notas al final del texto.

${ }^{96}$ Quizá quiera decir con dos cuernos, para indicar que se trata de una petición complicada. 
Mi entero, en suma, só un mancebo que debía... plaćer.

Só más presto alegre que serio; me plaće mucho la compañía -no de las Aguas-, ma aquea de las mujeres. Escribí sobre muchos sujetos; polemiquí en prośa, en poeśía y miśmo en esfueños. Me hiće tantos enemigos (por mis escritos) más muchos de mis conocidos. Me tienen por cruel y non lo só; me creen negro y es lo contrario. Sí, só irónico, lo atorgo.

El solo defeto que me puedrían topar es el querer espośar una niña hermośa, simpática, inteliǵente y aflijada de una... buena dote ${ }^{97}$.

Meldaderas y meldadores, ¿es esto un defeto o una pretansión? Según mí, la pretansión es un defeto.

Siño característico: me plaće mucho el güerto de Bešchinar y los artistas Gaspar y Neva.

SS.

(1) La redacción se reśerva el dirito de haćer reflexiones sobre los retratos. Cada reflexión non puedrá depasar una línia.

(2) Sin contar las noches.

(3) Aluśión al gusto de la múśica.

Sobre el portreto al que se refiere en el párrafo segundo puedo decir que en La gavilla pág. [5] aparece un retrato suyo, algo diferente al que he aludido arriba publicado por Pulido. En ambos y de acuerdo con lo que él mismo dice en la descripción que hemos leído, ostenta unos grandes mostachos tan del gusto de la época y una frente amplia. Vuelve a mencionar aquí al dentista Dr. Gateño, al que también se refería en el poema núm. 2 (v. 31) supra, y de su desamor por la Compañía de Aguas donde estaba empleado por esas fechas ya me he ocupado antes (apdo. 2 y texto núm. 1). Del jardín de Bešchinar y de la afición de Šalem por los artistas Gaspar y Neva que menciona volveré a ocuparme más adelante ${ }^{98}$.

Como ya decía arriba al ocuparme de la fecha de nacimiento de Šalem, la idea expresada por nuestro poeta de que en 1901 tenía 28 años parece reafirmar la alusión que se le hace en un poema publicado en La Época 27:1308 (15 tišrí 5662 / 27 sep. 1901, pág. 5c: vs. 14-16), probablemente debido a la péndola del poeta salonicense Alberto Taragano, quien fuera el rival acérrimo de Šalem en materias de estro poético y de cuya justa

\footnotetext{
${ }^{97}$ Irónica frase, ya que, si la presunta novia tiene una buena dote, no puede estar muy afligida.

${ }^{98}$ Sobre los Gaspar - Neva, vid. infra textos 9 (apdo. 5.3), 10 (apdo. 5.4) y 11 (apdo. 5.5) y mis correspondientes comentarios.
} 
poética me he ocupado en otra ocasión ${ }^{99}$. Mi suposición de autoría se basa en mi muy personal interpretación del verso final en el que, tras contar el poeta todas sus miserias, dice «mi alcuña es de... ano», lo cual he entendido como un juego de palabras con «Tarag-ano».

El texto de Taragano va precedido de la siguiente entradilla:

Muchos señores forasteros a la redacción de La Época mos adrezan sus portretos con rogativa de publicárselos. Les haćemos saber a estos señores que, después de terminar la seria de Retratos de muestros colaboradores, vamos a pensar si puedemos satisfaćerlos en publicando aqueos que mos parecerán interesantes.

En mientres, muestro reportier, la indiscreción de el cual no deǰa dingún duḅio, pudo retener en su memoria el portreto sigüente que se meldaba entre dos consumadores $[$ sic $]$ de un café.

El poema, sin título, consta de 44 versos que son pareados y dice así:

\section{Nostalgias de un viejo poeta}

1 Es solo delantre del espejo que creo que só manco viejo.

Ahí yo entero me espacio ${ }^{100}$, malgrado mi medio ĝeneracio ${ }^{101}$.

5 Yo con las boyicas y colores y los jabonicos de golores tapo mis rugas de hombre viejo, a un «jovanoto» asemejo. Ma un hábil fiśionomista

10 en su estudio que insista y verá un hombre maquiado de partida de años cargado. Conclusión: un hombre más de cocho. $\mathrm{Y} \mathrm{SS}^{102}$ con sus vente y ocho

15 está alegre y venturośo; de su mancebez yo só celośo. Me place todo modo de cencia

\footnotetext{
${ }^{99}$ Vid. Romero, «Poetas sefardíes».

${ }^{100}$ Quizá quiera decir que toma aire, que se ensancha.

${ }^{101}$ Es decir, que Taragano en estos momentos tiene en torno a la cincuentena.

${ }^{102}$ Escrito en letras latinas, según Šalem escribía siempre su seudónimo.
} 
y somporto con pacencia

y embebo... y non me arabio

20 cada noche ande el sabio de el esprito... reconfortante y otro estudio interesante, por que tome plaćer y consolo en la vida cale yiva solo.

25 Viviría mejor retirado, evito tomar baño yelado; el invierno me haće doliente, me consola el... lugar caente ${ }^{103}$. Só enemigo de lotería;

30 mi cara se haće amaría en viendo venir mis creditores, que son inferior a mis devdores ${ }^{104}$.

La única fortuna mía es el ser de grande famía.

35 No nombréš hecho de «menudallas», no posedo ni menos medallas.

No só mercader ni boticario, por esto quedí celiḅatario. El coredor ${ }^{105}$ ya viene, ma se va

40 siendo lo que trae es mi vavá ${ }^{106}$. 26 años tengo de empiego, conozco el turco y el grego, búlgaro, francés y italiano.

Mi alcuña es de... ano [= Taragano].

De todos los datos que conocemos de Šalem ninguno nos da la pista de su situación familiar, aunque algunas frases suyas parecen indicar que estaba soltero: «y sin ser aínda yerno» (texto 2 v. 28) y «me plaće mucho la compañía -no de las Aguas-, ma aquea de las mujeres» (texto 4), frase esta última -no dicha en privado, sino publicada en un periódico- que, de

${ }^{103}$ Los puntos suspensivos me hacen suponer que con «lugar caente» ('caliente') esté aludiendo a una relación sexual.

104 Es decir, que debe más dinero que el que le deben.

${ }^{105}$ Es decir, el casamentero. Se refiere a los que se ocupaban de buscar novios y novias.

${ }^{106}$ Es decir, que lo que el casamentero le ofrece como posible esposa es más vieja que su abuela (vavá). 
haber estado casado, no hubiera sido muy bien recibida por la sociedad de la época y ni qué decir tiene que menos por la presunta cónyuge. Y asimismo en las notas necrológicas que hemos leído sólo se da el pésame a los parientes es decir, a los padres.

\section{Los POEMAS De ŠLlomó ŠAlem}

Centrándonos ya en su producción poética, recordemos primero la frase de Nehama arriba $\operatorname{citada}^{107}$, quien decía de él que ha sido el mejor poeta en judeoespañol que produjera Salónica.

Attias $^{108}$, advirtiendo que sus materiales no son completos, nos ofrece una lista de 67 poemas, publicados todos ellos en el ya aludido periódico de Salónica La Época ${ }^{109}$ entre el 27 de octubre de 1899 y el 14 de junio de 1907. Aunque mis materiales tampoco son completos, puedo añadir a ellos los tres siguientes.

El primero apareció también en La Época (24: 1.177: 7 adar 5659 / 17 feb. 1899, pág. 6b). El poema no está firmado y sólo podemos averiguar la autoría gracias a la entradilla de la redacción del periódico ${ }^{110}$, que dice así:

Muestro colaborador SS mos adrezó la poeśía sigüente en repuesta a una otra que fue publicada en El Avenir ${ }^{111}$ de la semana pasada. Para que los lectores puedan entender, muestro colaḅorador mos roga de puḅlicar las dos poeśías una enfrente de otra.

Como bien dice Attias ${ }^{112}$, nuestro autor firmaba siempre sus artículos periodísticos con su nombre completo o con las siglas de su nombre ŠḤ̆

\footnotetext{
${ }^{107}$ En Histoire, pág. 756.

${ }^{108}$ En «Šelomó H.. Šalem», págs. 334-335.

109 Attias indica en su lista las fechas de publicación de los poemas, amén de señalar aquellos que además aparecieron en las dos recopilaciones de los poemas de Šalem a las que me refiero a continuación.

${ }^{110}$ Vid. Romero «Poetas sefardíes», donde publico el poema, que comienza «Esperanza: No, ¡oh, muevo poeta!», así como la entradilla aludida, que repito aquí.

${ }^{111}$ Otro de los más importantes periódicos de Salónica; vid. GAon, A Bibliography, núm. 2.

${ }^{112}$ En «Šelomó Ḥ. Šalem», pág. 323. 
en letras hebreas y sus poemas con las siglas SS en caracteres latinos. Quizá sea la ausencia de tales siglas lo que hizo que Attias no tuviera en cuenta este poema.

El segundo, así mismo publicado en La Época (27:1314: 4 kislev 5662 / 16 nov. 1901, pág. 3a), se titula Maestros y elevos, fantaśía en versos libres, y esta vez la firma del autor va en caracteres hebreos שש. Y el tercer poema, titulado Grito del corazón y que trata sobre las diferencias sociales, apareció en este caso en El Avenir (9:26: 26 siván 5666 / 19 junio 1906, pág. 6a), firmado como siempre SS en letras latinas, y está fechado en Kavala, el 13 junio de 1906. Así pues hasta el momento tenemos filiados un total de 70 poemas de nuestro autor.

\subsection{Recopilaciones de poemas}

Según Attias ${ }^{113}$, en 1901 apareció en Salónica una primera recopilación de sus poemas titulada Cuaderno de poeśías -que no he podido consultar- con 11 textos, y en diciembre de ese mismo año una segunda bajo el nombre de La gavilla / La gerbe con otros $17^{114}$. Y aún más, el propio Attias ${ }^{115}$, al ocuparse de un texto recogido de tradición oral y el cual pone en relación con el poema A mi amada de nuestro autor, dice que, a principios de 1967 y cuando estaba recopilando materiales para escribir una monografía sobre Šalem ${ }^{116}$, cayó en sus manos un librito titulado Cuaderno de poeśías, con 32 páginas, que el autor publicó a finales de marzo de 1901. Según ello, Cuaderno y Gavilla aparecieron ambos en 1901, el primero en marzo y el segundo a finales de año.

Sin embargo, dado que Gavilla apareció sin data y, al parecer, lo mismo sucedió con Cuaderno, no dejan de plantearme algunas dudas las rea-

${ }^{113}$ En «Šelomó Ḥ. Šalem», pág. 324.

${ }^{114}$ Sobre estas recopilaciones de poemas de Šalem, vid. Romero, Creación, pág. 214. Para La gavilla uso fotocopia del ejemplar de NLI 31V4463.

${ }^{115}$ En su Cancionero judeoespañol [en hebreo con introducción también en español] (Jerusalem: Centro de Estudios sobre el Judaísmo de Salónica, Tel Aviv, 1972) págs. 168-169.

${ }^{116}$ Se refiere a su muchas veces mencionado artículo «Šelomó Ḥ. Šalem». 
les fechas de publicación de ambas colecciones, e ignoro además en qué se basaba Attias para sus precisiones de año y meses.

Consultada la bibliografía de Dov Cohen ${ }^{117}$, vemos que -como Attiasindica para ambos libros el año de 1901, precisando lo siguiente en cuanto a sus dataciones: para Gavilla, que se basa en el anuncio aparecido en La Época (26:1283: 9 nisán 5661 / 29 marzo 1901, pág. 5) -anuncio sobre el que volveré más abajo-, y para Cuaderno dice que no lo ha visto y que lo fecha según la bibliografía de A. Yaari ${ }^{118}$.

Por su parte Yaari fecha efectivamente Cuaderno en 1901, marcándolo con asterisco para indicar que, si bien lo ha visto directamente, pertenece a una biblioteca particular y no a los fondos de la Biblioteca Nacional de Jerusalén. Pero en cuanto a Gavilla le adjudica la fecha de $1900^{119}$.

Y a todo ello hay que añadir los datos de M. Molho ${ }^{120}$, quien fecha Gavilla en 1900 y Cuaderno en 1901.

Veamos qué es lo que se dice en el anuncio que he mencionado antes, aparecido en La Época (26:1283: 9 nisán 5661 / 29 marzo 1901, pág. 5a) y en el que, al parecer, se basa Cohen para la fechación de Gavilla. Agradezco de todo corazón a Susy Gruss el haberme proporcionado reproducción del texto del periódico a partir del ejemplar conservado en el Instituto Ben-Zvi de Jerusalén. Y lo primero que me deja asombrada es el epígrafe del texto: Cuaderno de poeśía y no Gavilla. Dice así:

Muestro colaḅorador y amigo Se" Šelomó Šalem (SS) puḅlica estos días un cuaderno de poeśías escoǵidas entre aquellas que aparecieron en La Época y otras que no fueron aínda publicadas.

No hay dingún dubio que el pueblo va querer testimoniar su simpatía a un escribidor que hiźo pasar a todos muchos momentos alegres.

Si el autor, como lo esperamos y lo suhetamos cordialmente, es encorajado, él hará seguro su primo cuadreno [sic] de muchos otros.

${ }^{117}$ En The National Library of Israel, Bibliography of the Hebrew Book.

118 Abraham YAARI, Catalogue of Judaeo-Spanish Books in The Jewish National and University Library, Jerusalem [en hebreo] (suplemento de Kirjath Sepher 10, Jerusalem 1934) núm. 384.

119 YAARI, Catalogue, núm. 383.

${ }^{120}$ En Literatura sefardita, pág. 299. 
Publicamos aquí aḅajo la prefación que muestro capo redactor escribió para la prima bročhura y el portreto del autor.

Y este es el «Prefación» que firma Šemuel Sa'adi Haleví (ibid. pág. 5b-c), bajo una fotografía de Šalem, idéntica a la que figura en Gavilla (p: [5]):

Caro Šelomó:

Me demandas de escribir una chica Prefaz para tu bročhura. Debo atorgarte que non sé cuálas de tus poeśías te propones de reunir un cuadreno [sic]. Lo que sé de seguro es que todo lo que tiene salido de tu péndola fue siempre agradecido de parte los meldadores.

Si las poeśías que tú pensas haćer publicar en bročhura oḅtienen el miśmo succeso que tuvieron en el jornal, non es solo el triumfo, ma también la gloria que te espera.

Yo sería el primero a aplaudir a esta gloria, siendo me acodro con emoción los momentos que pasábamos en meldando tus versos antes de darlos a la publicación. Muchos de ellos mos hićieron haćer profundas reflexiones. «¿Cómo se puede, en medio de tantos emblorios $[\text { sic }]^{121}-$ mos dećíamos a la redacción-, escribir tan hermośos versos?». La sola espiegación que topábamos era que los embrollos ellos miśmos servían de manadero para la aḅundanza de tu producción.

Tus versos, endemás los chicos portretos y medallones, no se van embarar nunca de las mientes de muchos miles de meldadores. Tú estigmatiźates al pedante, el orgullośo, el ex́altado, el misteriośo, el rico, el empiegado. Cada hombre siendo un poco pedante, un poco orgullośo, un poco ex́altado, un poco misteriośo y miśmo un poco empiegado, todos los meldadores debieron de reconocersen un poco en cada uno de los portretos y a este título guadrar, si non ensuña, el suvenir de lo que tú diǰites. Ya remarcates que solo por el rico non dije, que cada hombre lo es un poco. Esto no impide que de tu poeśía sobre la gente fortunada se van a acodrar todos: los ricos por lo que los prometites puños, los otros por lo que les toca a dar estos puños. Dunque los unos y los otros se van acodrar; y para que se acodren también los que van a meldar esta bročhura, aresto aquí la Prefaz que se puede reśumir en dos fraśas:

A los negros puños,

puños a los negros.

Podemos pensar que el epígrafe Cuaderno de poeśía no se trate del título de la obra, sino que se refiera solamente a un libro con poemas. Y aunque

${ }^{121}$ Escrito אימבלורייוס, es decir embrollos. 
Haleví reconoce que no sabe qué poemas contiene la obra, en su Prefacio sí está aludiendo a varios poemas de Šalem que ya se habían publicado en La Época referidos a pedantes $(21 / 1 / 1900)^{122}$, orgullosos $(28 / 9 / 1900)$, exaltados $(5 / 10 / 1900)$, misteriosos $(28 / 12 / 1900)$, ricos $(8 / 3 / 1901)$ y empleados (22/2/1901). Menos el que Attias titula Un orgullośo, todos los demás aparecieron en Gavilla, denominados: Un pedante (Gavilla pág. 12), Un rico (Gavilla págs. 18-19) ${ }^{123}$, Un misteriośo (Gavilla pág. 24), Un ex́altado (Gavilla pág. 28) y Un empiegado (Gavilla págs. 31-32).

Pero, lo que sí queda muy claro de las palabras de Haleví es que esta obra es la primera recopilación independiente de poemas escritos por Šalem.

Sin embargo y para mayor confusión cabe decir que a mediados de diciembre -mes adjudicado por Attias para Gavilla- de 1889 -es decir, casi año y medio antes del anuncio de La Época que acabamos de leeraparecía en La Época (25:1218: 13 tebet 5660 / 15 dic. 1899, pág. 9a) y bajo el título de Poeśías diversas el anuncio de una futura recopilación de poemas de Šalem, que estas alturas no puedo asegurar cuál fuera de las dos. Esto es lo que leemos:

Según La Época lo tuvo anunciado, su colaḅorador $\mathrm{SS}^{124}$ ajuntó en una chica bročhura un cierto número de poeśías. Sobre la demanda del autor, muestro colaborador «Campo liḅre» escribió para el chico ubraje la corta Prefaz sigüente.

Tal Prefaz, titulado «Ỵierbo y medio», dice así:

Mi compañero de combate, SS, autor de este chico ubraje, me demanda de preśentar al pueblo. Esta preśentación era inútile. Ella es en miśmo tiempo difícile, siendo se trata de hablar en prośa de un grupo de poeśías de las cualas la más parte ya fueron publicadas y oḅtuvieron un succeso merecido.

Es justamente este succeso legítimo y la rogativa de muchos mancebos que deĉidieron mi colega a grupar en bročhura sus poeśías esparćidas

\footnotetext{
${ }^{122}$ Las fechas son las de la lista de AtTias, «Šelomó H. Šalem», pág. 334 y corresponden, respectivamente, a sus números 14-16, 21, 29 y 27.

${ }^{123}$ En su lista, Attias no indica que este poema apareciera en Gavilla.

${ }^{124}$ Siempre en letras latinas.
} 
en los jornales o guadradas en portafollos, de los cualos ellas haćían el único ornamiento.

¿Qué van a topar los lectores y sobre todo las amables lectoras en estas poeśías? Muchas cośas, entre las cualas el dulce suvenir de los momentos pasados a meldar y comentar aqueos versos que castigaban cada uno con una flor, con una pluma o con una palmatoria ${ }^{125}$ de velludo, ma que no era manco una palmatoria ${ }^{126}$.

En verdad eran bien dulces aqueos momentos ande grupos de jóvenes y frescas hijas se reunían y trocaban sus impresiones sobre lo que dijo SS, sobre lo que le aconteció por haber tuvido el coraje de pensar liḅremente y sobre muchas otras cośas. Es estos y más otros suvenires que van a topar en la preśente bročhura.

Estos suvenires se esparten en alegres y tristes, según que hablan de probedad o riqueźa; en moralicos o volterianos, según que se habla de Mišlé ${ }^{127}$ o de el avenir ${ }^{128}$; en divirtientes y instructivos, según que se trata de castigar un edirnilí o de dar una lición de corteśía a... otro poeta.

En fin -y es sobre este punto que quero escapar el «Ỵierbo y medio»-, hay al cabo de esta bročhura versos que se cantan al son de «Las estreas en los cielos» y la «Soledad de la mañana». Y es el mejor merecimiento para esta chica obra de escaparse en cantando.

Como vemos, se precisa que la mayoría de los poemas ya se habían publicado en los periódicos - «esparćidos en los jornales»- en tanto que otros permanecían inéditos - «guadrados en portofollos»-; y en cuanto a su contenido, entre otras cosas, se indica que son: «divirtientes y instructivos, según que se trata de castigar un edirnilí o de dar una lición de corteśía a... otro poeta».

Quizá la palabra edirnilí venga a apoyar la opinión de que la obra anunciada fuera Cuaderno y ello en contra de lo que yo misma decía hace años ${ }^{129}$, ya que no encuentro en Gavilla ninguna mención de un edirnilí (de Adrianópolis, Edirne); sí se alude a un manastirlí (de Monastir) en el poema titulado Utopía de Gavilla, pero no en la versión que apareció

\footnotetext{
${ }^{125}$ Se refiere a las palmetas con las que los maestros golpeaban a los niños en las manos para castigarlos; vid. NeHAMA, Dictionnaire, s.v. palmatórya.

${ }^{126}$ Es decir, que aunque fuera de terciopelo, no por ello dejaba de fustigar.

${ }^{127}$ Se refiere al libro bíblico de Proverbios.

${ }^{128}$ Que no sé si se refiere al futuro o al periódico de Salónica llamado El Avenir.

${ }^{129}$ En Romero, «Poetas sefardíes».
} 
en este libro, sino en la que se publicó en La Época 25:1232 (20 adar II 5660 / 23 marzo 1900, pág. 7b), en cuyo v. 7d leemos «del manastirlí Maslíahı ${ }^{130}$.

Pero no acaban aquí mis dudas. Por un lado, al final de Gavilla (págs. 33-40) sí aparecen las versiones en verso y parafraseadas de los primeros versículos de los capítulos 1-29 de Proverbios, lo cual coincide con lo que nos dice «Campo libre»; pero por otro, no figura en este libro ningún poema que haga referencia a las canciones «Las estreas en los cielos»y la «Soledad de la mañana» ${ }^{131}$, que indica el autor del Prefaz, títulos que tampoco parecen corresponder a poemas suyos y que no figuran en la lista de Attias ${ }^{132}$.

${ }^{130}$ Vid. Romero, «Poetas sefardíes», núm. 6.

${ }^{131}$ Cabe mencionar que Atтias en Cancionero judeoespañol (págs. 93-94, núm. 28) recoge una canción que comienza «La soledad de la nochada», que no sé si puede tener alguna relación con la mencionada. Sobre estas dos canciones debo mencionar lo siguiente. El/La amable y anónimo/a informador/ra de este artículo para su publicación en Sefarad ha hecho el siguiente comentario que agradezco de corazón y que reproduzco. Sobre la primera canción dice: «"Las estreas en los cielos" or "Las estreas de los cielos" is the opening verse of a stanza from the well known cantiga Las horas de la vida, whose most common opening verse is "A la una yo nací" (or "A la una nací yo"), e.g. Attias, Cancionero, no. 1». Efectivamente así comienza el primer verso de la estr. 4 del mencionado texto que recoge AtTias en Cancionero judeoespañol págs. 51-53, grabado a su madre Palomba Attias (nacida en Salónica en 1870), indicando en su amplio comentario que el texto procede de la tradición hispana y que estaba muy difundido en la tradición sefardí de los Balcanes, remitiendo a versiones recogidas por musicólogos estudiosos de la tradición sefardí, los cuales han recogido versiones desde principios del siglo XX, algunas de las cuales comienzan con el verso citado de «Las estreas de los cielos». Sobre la segunda canción dice: «I am quite sure it refers to "La soledad de la nochada"», eliminando las dudas que he expresado al principio de esta nota. El anónimo informador aún añade en su comentario lo siguiente (el texto entre corchetes es mío): «To my understanding, the fact that these íncipits do not appear in Gavilla mean that the writer knew them orally, with their music. These references, combined with the 2 songs Attias included in his Cancionero, mean that at least 4 of Šalem's poems were actually sung. Furhtermore, "Ah niña llena de brillo" [vid. apdo. 4.2 infra y nota 134] was evidently very popular, since it was recorded by Haim Effendi in 1907/8. See Edwin Seroussi y Rivka Havassy (commentaries) and Joel Bresler (recording research), An Early Twentieth Century Sephardi Troubadour: The Historic Recordings of Haim Effendi of Turkey (Jerusalem 2008) (Anthology of Music Traditions in Israel, 21, AMTI 0801), CD 3, no. 5».

${ }^{132}$ En «Šelomó Ḥ. Šalem», págs. 334-335. 
Ante todo lo expuesto, debo subrayar que no deja de parecerme extraño que, si ya en La Época de mediados de diciembre de 1899 se anunciaba la aparición de una de las compilaciones poéticas de Šalem, esta-fuera cual fuera- tardara un año y medio en ver la luz, cuando lo previsible es que hubiera aparecido en 1900.

Cabe resaltar que los poemas de Šalem publicados en La Época presentan variantes en ocasiones de calado con los que aparecieron recopilados en Gavilla. Ignoro si lo mismo sucedía entre los que aparecieron en el periódico y los recogidos en Cuaderno, que, como ya he dicho, no he podido consultar y que al parecer solo han visto Yaari y Attias.

\subsection{Poemas de Šalem editados modernamente}

Como he indicado arriba (apdo. 2), Attias transcribe nueve de sus poemas, los titulados: Abril (pág. 327), Orgullo (págs. 327-328), Una verdad (pág. 328), Un hipócrita (págs. 328-329), Un celośo (pág. 329), Un orgullośo (págs. 329-330), El exilado (págs. 330-331), Todos mueriremos (págs. 331-332) y A ella (págs. 332-334), y había publicado antes ${ }^{133}$ uno más sin título, que comienza «Ah, niña, llena de brillo» ${ }^{134}$.

Y yo misma me he ocupado en varias ocasiones de las poesías de Šalem, editando y aludiendo a los siguientes diez poemas ${ }^{135}$ :

- 1. (Sin título) Inicio: «Esperanza: No, ¡oh, muevo poeta!» (RomeRO, «Poetas sefardíes»; no en AtTIAs, «Šelomó H. Šalem»).

- 2. Las angustias de mi vida (ROMERo, «De ruidos callejeros» ${ }^{136}$, núm. 1) / Las angustias de mi vida (AtTIAS, «Šelomó Ḥ. Šalem», núm. 1).

${ }^{133}$ En Cancionero judeoespañol, págs. 169-171, núm. 89.

${ }^{134}$ Attias (Cancionero judeoespañol, págs. 169-171, núm. 89) dice que había aparecido en La Época el 2 de enero de 1902; sin embargo el propio AtTIAS en «Šelomó H. Šalem» (núm. 40) lo fecha en el mismo día y mes, pero de 1903.

${ }^{135}$ En la lista que sigue ordeno los textos según su cronología; anoto en primer lugar mis títulos -cuando los hay-o su inicio, seguidos (entre paréntesis) de las pertinentes remisiones bibliográficas, a lo que añado (tras barra inclinada) los títulos originales, seguidos (también entre paréntesis) de la numeración que tienen los poemas en la lista de Attias.

${ }^{136}$ Elena Romero, «De ruidos callejeros: Las ciudades de Salónica y Esmirna según las escucharon tres poetas sefardíes», en Lengua, Llengua, Llingua, Langue: Estudios en 
- 3. (Sin título y de dudosa autoría de Šalem) (Romero, «Poetas sefardíes») / Mal de muchos consolación de bobos (AtтiAs, «Šelomó H.. Šalem», núm. 5).

- 4. Contra los poetastros (Romero, «Poetas sefardíes», núm. 4) / Protestación (AtTiAs, «Šelomó Ḥ. Šalem», núm. 6).

- 5. A un poeta ofendido (Romero, «Poetas sefardíes», núm. 5) / Deśmentido (AtтiAs, «Šelomó Ḥ. Šalem», núm. 7).

- 6. Utopía (Romero, «Poetas sefardíes», núm. 6) / Utopía (AtTiAs, «Šelomó H. Šalem», núm. 8).

- 7. Un advenedizo (Romero, «Poetas sefardíes», núm. 1) / Un parvenido (AtTiAs, «Šelomó Ḥ. Šalem», núm. 13).

- 8. Un pedante (Romero, «Poetas sefardíes», núm. 2) / Un pedante (AtтiAs, «Šelomó H. Šalem», núm. 14).

- 9. Los afeminados de antaño (RoMERo, «Poetas sefardíes», núm. 7bis) I Esto hay en el mundo (AtTiAs, «Šelomó Ḥ. Šalem», núm. 25).

- 10. Elul (o el degollío) (Romero, «Sefardíes "indignados"» ${ }^{137}$, apdo. 3) / Elul o el degollío (AtTiAs, «Šelomó Ḥ. Šalem», núm. 34).

\subsection{Contenido de los poemas}

Según el propio autor reconoce en su Retrato, tanto Attias como yo misma hemos destacado el contenido satírico, humorístico y en ocasiones de acerba crítica de la mayoría de sus poemas, lo cual también fue la tónica de sus artículos periodísticos. Puede servir como ejemplo de los temas que tocó y criticó el siguiente poema que se publicó en La Época $\left(2[7]^{138}: 1313,23\right.$ ḥešván 5662 / 8 nov. 1901, pág. 4c) con el título de ¿Cuándo? ${ }^{139}$. Está formado por 42 versos, que son pareados y que presento como en anteriores textos.

homenaje a la profesora Beatrice Schmid, coords. Yvette BürKI, Manuela CIMELI y Rosa SÁNCHEZ (München: Peniope, 2012) págs. 374-389.

${ }^{137}$ En Elena Romero, «Sefardíes “indignados” por los desahucios en la Salónica de 1898-1901», MEAH: Sección Hebreo 61 (2012) págs. 159-183.

${ }^{138}$ El número que pongo entre corchetes parece ser un 2.

${ }^{139}$ Vid. Attias, «Šelomó Ḥ. Šalem», núm. 33. 


\section{6. ¿Cuándo?}

1 ¿Cuándo verná tiempo de las maravías que los jornalistas no hablarán mentiras, los doctores sanarán a sus haćinos, no habrá pleito más entre los većinos;

5 dejarán en repośo a los devdores..., no serán más fišugos los coredores, emỵeźarán la ĝente oficio de mano, el rico se mostrará más humano; al probe en invierno le darán carbón,

10 no dejarán más falsificar el jabón, de los caballos del tram ternán piadad, mos meterán más luź en la civdad, en las caes no habrá lodo ni caño, las quierás pagar a mes y no a año,

15 derocarán las baracas de afuera, habrá paz entre esfuegra y nuera, no dirán minhá y 'arḅit en los cafés, los que llevan chapeo se meterán fez, los uśurieros serán más piadośos,

20 habrá diminución en los hạadrośos, los dantistas curarán bueno los dientes, quen tiene ayudará a sus parientes, los mestros se mostrarán manco crueles, los empiegados serán todos fieles,

25 entre ellos habrá más solidaridad, harán reformas en muestra comunidad, las niñas quedarán de ser provocadoras, las mujeres no serán más jugaderas, irán todos en verano a Bešchinar,

30 el tram por la Ištirá harán caminar, ternán buen comporto los muhtares, en los cafés habrá modos de cantares, mos traerán en Salonico este par que todos adoraban: Neva y Gaspar,

35 mos fraguarán Talmud Torá y hespital?

Cuando mośotros veremos un día tal, estonces dirán hombres y animales: «Aribó fin para todos muestros males». Cantemos todos de goźo y alegría, 40 ni en Miŝráyim hubo esta maravía. 
¿Queréš saber cuándo esto se espera?:

cuando subirá el aśno de la escalera ${ }^{140}$.

Se mencionan en el texto una serie de cuestiones, varias de las cuales reflejan los problemas de la población salonicense en general y judía en particular. A continuación ofrezco unos someros datos bibliográficos remitiendo a algunos autores que se han ocupado de tales temas (entre paréntesis remito a los versos del poema de Šalem).

De que en la Escuela de la Alianza, inaugurada el 15 de octubre de 1873, se enseñaban también oficios a sus alumnos se ocupa Nehama ${ }^{141}$, aunque a Šalem no le parece suficiente (v. 7). De los grandes fríos que podían desatarse en la ciudad (v. 9) y de allí la necesidad de carbón para calentar las viviendas, nos habla Nehama ${ }^{142}$. A los tranvías tirados por maltratados caballos (v. 11) y que se inauguraron en 1893, se refieren Saporta y Molho ${ }^{143}$. De la mala o nula luz eléctrica en determinados barrios de la ciudad (v. 12), del barrio de la Ištirá (v. 30), donde se encontraba el gran centro comercial de importadores y comerciantes de cereales, y de los jardines de Bešchinar (v. 29) podemos encontrar datos dispersos en Toledano, Saporta, Molho y Romero ${ }^{144}$. Las quejas por el polvo y el barro de las calles (v. 13), problema que hacia 1926 aún no se había solucionado, se expresan también en el poema que titulo La nueva Salónica ${ }^{145}$. De los problemas del pago anual de los alquileres (v. 14) me he ocupado yo misma ${ }^{146}$ y también de la

\footnotetext{
${ }^{140}$ Es decir, por la escalera.

${ }^{141}$ En Histoire, vol. VII, págs. 666-686: esp. págs. 681-682.

${ }^{142}$ En Histoire, vol. VII, pág. 620.

${ }^{143}$ Vid. SAPORTA y BeJA, En torno de la Torre Blanca, págs. 157-158; y Molho, «Hašejunot», pág. 21.

${ }^{144}$ Vid. Hayim A. TolEdANo, «Hayehudim behayé hamisḥar vehata'asiyá šel Saloniqui», en Zijrón Saloniqui ..., redactor David A. Recanati (Tel Aviv 1986) vol. II, págs. 202-207 (resumen en judeoespañol en letras latinas: «Los jidios en la vida comerciala i endustriala de Salonique», en pág. 28): págs. 204-205; SAPORTA y BejA, En torno de la Torre Blanca; MolHo, «Hašejunot», págs. 20-21; y RoMERo, Entre dos (o más) fuegos, Índice onomástico y geográfico, s.p.v.

${ }^{145}$ Editado en Romero, Entre dos (o más) fuegos, págs. 671-673, núm. 146; vid. allí la bibliografía que recojo de otras versiones publicadas.

${ }^{146}$ En Elena RomERo, «Sefardíes “indignados”».
} 
afición de las mujeres al juego (v. 28) ${ }^{147}$. De que los judíos se reunían en cualquier sitio, como, por ejemplo, las esquinas de las calles, para decir las oraciones de minhá y 'arḅit (v. 17), nos habla Nehama ${ }^{148}$, quien también se refiere $^{149}$ al uso del fez y del sombrero a la europea (v. 18). De los castigos corporales a los alumnos en las escuelas (v. 23) se ocupa Molho ${ }^{150}$. En cuanto a los muhtares (v. 31) o jefes de barrio, encargados, entre otras muchas cosas -como, por ejemplo, de cobrar los impuestos ${ }^{151}-$, de reclutar allí donde los encontraban a los jóvenes que se habían escaqueado de la llamada a filas, servicio militar al que los judíos estaban obligados desde la subida al poder de los Jóvenes Turcos en 1908, puede verse, por ejemplo, lo que he dicho yo misma ${ }^{152}$. Del hospital judío (v. 35), que se estaba construyendo por aquellos años en Salónica con la subvención del Barón Hirsch y que nunca acababa de inaugurarse, se habla en varios artículos de La Época de esas fechas, por ejemplo en este mismo número donde aparece el poema (pág. 7a). Y de la situación del Talmud Torá a finales del siglo XIX (v. 35), reconstruido en 1884, destruido en un incendio en 1898 y vuelto a reconstruir hacia 1901, se ocupa ampliamente Nehama ${ }^{153}$.

Entre tanta crítica declara también Šalem su afición a la pareja de cantantes aquí llamados Neva y Gaspar (v. 34), de los que volveremos a ocuparnos más abajo (textos 9 v. 55, y 10-11). Y, por último afirma irónicamente (v. 40) que, si todas las cosas mencionadas se arreglaran, habría que considerarlo como un milagro mayor que el que vivieron los judíos en su salida de Egipto. El texto se remata (v. 42) con un nada esperanzador refrán.

${ }^{147}$ Vid. Elena Romero, Y hubo luz y no fue tan buena: Las coplas sefardies de Purim y los tiempos modernos (Barcelona: Tirocinio, 2008), y «Textos poéticos sobre la emancipación de la mujer sefardí en el mundo de los Balcanes», Sefarad 69:1 (ene.-jun. 2009) págs. 173-227, y 69:2 (jul.-dic. 2009) págs. 427-476.

${ }^{148}$ En Histoire, vol. VII, pág. 616.

149 Histoire, vol. VII, pág. 626.

${ }^{150}$ Michael Molho, Usos y costumbres de los sefardíes de Salónica (Madrid Barcelona: CSIC, 1950) págs. 116-118.

151 Vid. al respecto NeHAma, Histoire, vol. VI, pág. 153.

152 En Entre dos (o más) fuegos, cap. 10, núm. 81.

${ }^{153}$ En Histoire vol. VII, págs. 641-652. 


\section{Los cafés Cantantes de Salónica, SEgún las CRÓNICAS de Šelomó ŠALEM}

Una faceta aún no estudiada de Šalem es la de su crónica de los cafés cantantes de Salónica, plasmada en su serie de poemas dedicados a describir las atracciones de tales cafés, de los que hace algún tiempo se ocupó Alberto Conejero ${ }^{154}$.

Conozco cinco poemas, publicados todos en La Época: dos en 1900, otros dos en 1901 y uno en 1903. La serie constituye un a modo de cartelera de espectáculos en verso que se plasmaría probablemente en más textos que los que han llegado a mis manos. Pero como muestra puede «bastar este botón» que ahora presento, ateniéndome a la cronología de los textos.

Esta actividad suya no deja de asombrarme, ya que en el Retrato que hemos leído arriba (texto núm. 4) él mismo declaraba: «Más presto llamad oreja (3) lo que tengo y non oído», especificándose en la nota 3 y para que no quede duda alguna: «Alusión al gusto de la múśica»; y asimismo en el primer poema de esta serie (texto núm. 7) reconoce (vs. 15-17) su incapacidad para distinguir las óperas de Hernani y El trovador. Veamos los textos:

\subsection{Los cafés cantantes de Salónica: una visión general}

El primer poema apareció en La Época 25:1221 (5 šebat 5660 / 5 enero 1900, pág. 10a) $)^{155}$, firmado como es habitual SS y titulado Un giro en los cafés. Consta de 48 versos, agrupados de cuatro en cuatro, que son pareados; intento separarlos por temas.

\section{Los cafés cantantes de Salónica}

1 No es más agora los tiempos de antes, en todos los cafés hay bailes y cantes.

\footnotetext{
${ }^{154}$ Alberto CONEJERo LóPEZ, «Cantos satíricos sobre la mujer moderna en Los cantes de la Trompeta y Los cantes de la Gata», en Judeo Espaniol: Textos satíricos judeoespañoles de salonicenses o sobre salonicenses, eds. Rena MolHo, Hilary Pomeroy y Elena Romero (Thessaloniki: Ets Ahaim Foundation, 2011) págs. 177-195.

155 AтtiAs, «Šelomó Ḥ. Šalem», núm. 2.
} 
Si van a la Olimpia, «Pol Lus y Fercot ${ }^{156} »$, alegres cantigas al son de Sukot.

$5 \quad$ Al café de a'lado es el Imperial; dos pasos camina, ves el Ruayal. Al primo se siente todo «Proto Mayo», ahí van mujeres y miśmo con sayo. En el otro cantan a uśo felaj ${ }^{157}$,

10 de todas las partes no sientes que ;aj...!; la áraḅa baila a la serpantina.

Ríndete al Olimp, es la estudiantina; todo lo que haćen es bueno y justo, ahí no frecuentan que hombres de gusto.

15 Hićieron un cante, yo creí Hernani. Me diće un amigo: -Vate haćer «nani» ${ }^{158}$; se ve que de esto no sos amator, esto que cantaron es del Trovator-. Quien me dij̄o esto es de mi alcuña,

20 no creas, amigo, que guadrí ensuña.

Pascual y Colombo dos tipos contrarios: el uno se pasa con los escolarios, el otro deśea la aristocracía, cuatro gruš poltrona, dos grušes la sía.

25 Pascual ya mos trujo a Vanda Vandina ${ }^{159}$, en junto con Ari ${ }^{160}$, otra siñorina.

A todos mos plaće el cante español, ellas mos atiran como el rosiñol. El baile que haćen es muy grandiośo, 30 todo asistiente se hinche de goźo.

${ }^{156}$ Los nombres escritos: פול לוס, פ׳ירקוט; pero no puedo asegurar que no se trate de tres personas distintas.

${ }^{157}$ Esta palabra y la de rima del verso siguiente terminan en $\mathrm{kaf}$ final.

${ }^{158}$ Las comillas en el texto. Es decir, vete a acunar al niño o a dormir como si fueras un niño, vete a hacer ro ro; vid. Nehama Dictionnaire s.v. nánni nánni-quien tiene la palabra por italianismo-, donde la explica como nana, cancioncilla para dormir a los niños y la expresión fazer nanni como «faire dodo».

159 Escrito ב'אנדה ב'אנדינה.

${ }^{160}$ Escrito ארי 
Por Monmart Doré ${ }^{161}$ no cale que hable, todo lo que haće es inimitable.

Póbero Colombo: trae duetistas, en većes combina ${ }^{162}$ que no son artistas.

35 Al Teatro Edén son las tres hermanas, las conocen todos a estas romanas. Italiano, grego y francés mos cantan, todos los oentes ya se apercantan.

Ellas son honestas, ellas son graciośas

40 y chica y grande todas deliciośas. Haćen lo que pueden sus adoradores, asentarsen cerca a sus deredores.

De estos cafés y yo só cliente, cuando los frecuento salgo sin devente.

45 Yo me vo en caśa amargo de alma; el pecho vaćío ${ }^{163}$ m'echo a la cama, prometiendo siempre de no salir más, veo con regreto que estó «olmás» ${ }^{164}$.

En el texto se mencionan una serie de locales de Salónica: Olimpia, Imperial, Ruayal, Olimp y el Teatro Edén, y por lo que se dice parece que los tres primeros están situados muy cerca unos de otros (vs. 5-6). Quizá cabe pensar que su localización fuera en los entornos de la plaza Olimpia, en el centro de la ciudad.

A un denominado Café Olimpio, situado al borde del mar, se refiere un artículo de La Época (núm. 411) del 16 de noviembre de 1883 (págs. 446a448a), firmado por S. Haleví -quizá Sa'adi Haleví, fundador del periódico-, donde se nos cuenta el grave rifirrafe habido entre él y un camarero, ya

${ }^{161}$ Escrito מונמארט דורי.

${ }^{162}$ Es decir, sucede.

163 Atendiendo a lo que se ha dicho dos versos antes, quizá quiera decir que se ha quedado sin dinero.

${ }^{164}$ Las comillas en el texto. La palabra turca olmaz como exclamación significa: ‘¡No, esto es imposible!, ¡no lo debes hacer!’ (vid. James RedHouse, New Redhouse TurkishEnglish Dictionary [9 ${ }^{\mathrm{a}}$ ed. Istanbul: Elif Ofset, 1987] s.v. ol- $2^{\circ}$ ). 
que habiéndose sentado Haleví cierto sábado en una de las mesas colocadas en el exterior del local, el camarero le exigió que le pagara antes de servirle, aunque sabía que Haleví era judío y no podía usar dinero en sábado.

No creo que se trate del mismo Olimpia mencionado en nuestro texto un llamado Cinema Olimpia o Cinema Teatro Olimpia, en el barrio del Vardar, del que he recogido noticias de representaciones teatrales desde $1931^{165}$. Por su parte Tomanas ${ }^{166}$ se refiere a un coffee-house Olympia, que se abrió tras el fuego de 1917 en un nuevo edificio y que por la fecha no parece tampoco tener nada que ver con el aquí mencionado. Tampoco sé si hay que identificar como un sólo local los llamados Olimpia y Olimp.

En cuanto al Teatro Edén, también llamado Edén Cinema y Edén Teatro y cuyo propietario era -al menos en 1903 y 1904- el sefardí Lieto Nóah ${ }^{167}$, también he documentado numerosas representaciones teatrales allí organizadas desde 1899 en adelante ${ }^{168}$.

No puedo afirmar si el aludido Colombo es el nombre de un local o de un empresario, pero me inclino por lo primero, ya que en Salónica había una plaza llamada Cristóbal Colón (o Colombo). Al respecto nos dice Saporta $^{169}$ : «El cuartier Colombo [en la Ciudad Vieja] ofrecía sus numerosos "café-chantán” y kavanés».

En cuanto a Pascual, más bien creo que en este caso sí podría tratarse del nombre del empresario del local.

Alude también Šalem al repertorio de tales locales, anotando los nombres de algunos cantantes: Pol, Lus y Fercot del Olimpia (v. 3); Vanda Vandina y Ari (vs. 25-26), de Pascual; y Monmart Doré (v. 31). Agradezco a Aitor García Moreno los datos que me ha proporcionado de algunos de estos artistas y que recojo a continuación.

De un tal Fercot tenemos noticias de sus actuaciones en Francia fechadas en 1912 y 1918. La diferencia de años con su actuación en Salónica en 1900 me hace dudar, sin embargo, de si se trata de la misma persona. El

\footnotetext{
${ }^{165}$ Vid. ROMERo, Repertorio, Índices, s.p.v.

${ }^{166}$ Kostas Tomanas, The Coffee-houses of Old Thessaloniki (s.l.: Nissides Publishing House, 1997) págs. 25-26.

${ }^{167}$ Vid. Romero, Repertorio, núms. 175 y 183.

${ }^{168}$ Vid. Romero, Repertorio, Índices, s.p.v., y Entre dos (o más) fuegos, cap. 7 B.

${ }^{169}$ En En torno de la Torre Blanca, pág. 215.
} 
periódico La Lanterne: «Journal Politique Quotidien» de 13 de diciembre de 1912 en la colaboración titulada «Concerts et spectacles divers» anuncia una fiesta de beneficencia que tendrá lugar en el Excelsior-Cinéma-MusicHall de París y en la que, entre otros artistas, actuará uno llamado Fercot, del que no se dice nada más. Y en el periódico Le Populaire: «Journal-Revue Hebdomadaire de Propagande Socialiste» de 14 de octubre de 1918 en la colaboración titulada «Soirées populaires à la Mairie de Saint-Ouen», se dice que hoy y mañana se inauguran las «Soirées populaires» en las cuales y entre otros artistas actuará «Fercot, chansonnier humoristique».

Más sorprendente es el caso de la llamada Vanda Vandina. En el Program-Bladet ('Cartelera de espectáculos') de Helsinki de 29 de noviembre de 1895 aparece el programa de un amplio concierto de 16 números organizado por el Socielethuset de la ciudad para los días 29 y 30 de noviembre. El programa se presenta como sigue: un recuadro central y a izquierda y derecha las actuaciones de los días 29 y 30 . En ambos textos, para la primera parte del programa y entre los números musicales, figura en el núm. 6 la actuación de Wanda Wandina, con una «chansonette» (sic: $c f$. fr. chansonnette) o cancioncilla, y en el núm. 13 vuelve a aparecer nuestra Wanda en el texto de la izquierda ahora como «soubrette», es decir, graciosa en el lenguaje teatral, repitiéndose en el texto de la derecha lo de «chansonette», igualmente mal escrito.

También se refiere nuestro cronista a los repertorios usuales de los cafés. Los alegres cantares de Sukot del café Olimpia (v. 4) quizá haya que ponerlos en relación con lo que dice Molho ${ }^{170}$ acerca de la costumbre de cantar a voz en cuello durante dicha fiesta y de la emulación que surgía entre los vecinos para ver quien cantaba más alto en las cabañuelas montadas en casas y barrios.

En relación con el Imperial se nos dice que es «Proto Mayo» (v. 7), es decir, Primero de mayo. Respecto a esa fiesta griega y a su celebración, nos dice Saporta ${ }^{171}$ que los griegos decoraban las puertas de las casas con coronas y guirnaldas de flores y de ramos de olivo. Según ello, Šalem podría estar aludiendo a determinadas canciones típicas de tal ocasión o a la decoración del local.

\footnotetext{
${ }^{170}$ En Usos, págs. 219-220.

${ }^{171}$ En En torno de la Torre Blanca, pág. 184.
} 
En cuanto al café Ruayal lo que se ofrecía eran cantes y bailes «uśo felaḥ», es decir, canciones folclóricas de tradición turca en la que no faltaba una áraba que «baila a la serpantina» (v. 11). Al respecto agradezco la precisión de Doğa Subaşı, quien me ha indicado que se trata de un baile en el que, con el cuerpo y las manos, los bailarines imitan los movimientos de una serpiente y que no tiene nada que ver con la danza del vientre, como yo en un principio había supuesto.

En el Café Olimp se podían escuchar operetas de Giuseppe Verdi, como Hernani y El Trovador (vs. 15-18), interpretados por la llamada «estudiantina» (v. 11), que no sé quiénes son. Los duetistas del Colombo no parecen gustar mucho a Šalem (vs. 33-34). Y en el Teatro Edén actúan tres hermanas romanas -o quizá rumanas- que cantan en italiano, griego y francés (vs. 35-37).

En cuanto al público y atendiendo a los locales, vemos como al Imperial van «mujeres y miśmo con sayo» (v. 8); en el Café Olimp se reúnen los «hombres de gusto» (v. 14); Pascual también atrae a los estudiantes (v. 23); y el Colombo se especializa en la aristocracia, lo que, al parecer, supone precios más caros (vs. 23-24).

Resulta de especial interés para los españoles las palabras de Šalem, que reflejan el éxito que cosechaban en Salónica los cantantes de nuestro país o que cantaban y bailaban canciones españolas (vs. 25-30). Tal atractivo también lo encontramos reflejado en la carta de Moisés Abravanel a Ángel Pulido ${ }^{172}$, donde, sobre un espectáculo organizado en Salónica hacia 1896, leemos lo siguiente (respeto la grafía del original, pero la puntuación es mía):

Ay circa 8/9 años vino a nuestra ciudad un couple de duetistas españoles llamados Lina Serano. El arivo fue como un evenimento para nosos; todos fuemos a sentirlos: «Mira como hablan», disian los unos; «Son Judios», disian los inorantes (siendo el que habla español es judio para los no istruidos). Todos aprendimos con curiosidad las cantigas por cantarlas a nuestras madres y siempre en el publio [sic, público], quando algun duetto viene, le demandan las cantigas del Chiquito del Amor, etc. etc.; i los españoles son mirados con sucesso.

${ }^{172}$ En Pulido, Españoles sin patria, págs. 442-443. 
E igualmente nos dice Saporta ${ }^{173}$ :

Ma, lo que plaćía lo más al público, en maýoritá jidió, era cuando algún cantador español o sefardí (dićiendo serlo) cantaba en esta lingua. No sólo porque era la de los selaniclís, ma porque, sin darse cuento, sus descendencia de España se arreyuelvía en ellos en oyendo cantar:

Si en tu ventana pośa una paloma, trátala con cariño que es mi persona;

o esta otra a doble senso:

Tápame, tápame, tápame tápame que tengo frío.

Si tú quieres que te tapen, que te tape tu marido;

o bien

$$
\begin{aligned}
& \text { Caballero de gracia me llaman } \\
& \text { y efectivamente yo lo soy. }
\end{aligned}
$$

Tales canciones españolas trasvasaron fronteras, haciéndose muy populares por todo el mundo. La primera, titulada La paloma, la compuso el vasco Sebastián de Iradier y Salaverri (1809-1865) hacia $1863^{174}$. La segunda, copla picaresca también muy difundida, la compusieron en su juventud Antonio López Mónis (letra) y Ricardo Yust García (música), muerto este último en 1968. Y la que empieza «Caballero de gracia» y que sigue «y efectivamente soy así» -tal y como la cantaba mi abuelo Luis- pertenece a la zarzuela así llamada y también La Gran Vía, con música escrita por Federico Chueca y Joaquín Valverde y estrenada en Madrid el 2 de julio de 1886.

\subsection{Alabanza a algunos cantantes}

El segundo texto, titulado Cośas buenas, apareció en La Época 25:1242 (11 siván 5660 / 8 junio 1900, pág. 10b) y Attias ${ }^{175}$ señala que

\footnotetext{
${ }^{173}$ En En torno de la Torre Blanca, pág. 159.

${ }^{174}$ Sobre la difusión de esta canción española en el mundo sefardí, puede verse Rivka HavassY, «El cancionero judeoespañol en transición: Un estudio de dos compilaciones de mujeres sefarditas del siglo XX», Ladinar VI (2012) págs. 165-192: 182-186. Debo esta referencia bibliográfica al/a anónimo/a informador/ra que he mencionado en nota 131 supra.

${ }^{175}$ En «Šelomó Ḥ. Šalem», núm. 9.
} 
también se publicó en Cuaderno. En la versión del periódico el texto está presentado a dos columnas y sin separación entre versos; consta de 38 versos, que son aleluyas, y dice así:

\section{Cantantes en Salónica}

1 Si querría haćer lista del que es vero artista, uno sólo toparía y esto por maravía.

5 No creáš que es cośa vana si vos digo que Cavana ${ }^{176}$ es el solo duetista que pueda sufrir mi lista.

¿Quién de vośotros, buen lector,

10 que fue un espectator no quedó él encantado de lo que haben cantado? Presteźa en transformación ${ }^{177}$, justeźa en imitación,

15 expresión en su mirada y vivez en su ojada.

En Cavana se remarca su compaña ${ }^{178}$ miśma marca: esbeltez y buena pośa

20 es dono de esta rośa. Su habla es muy graciośa, su diviśa es gustośa; ganaron la simpatía miśmo de mi vieja tía.

25 Cuanto a señor Visconte ${ }^{179}$ algo cuanto cale conte; ma el tiempo non permete,

\footnotetext{
${ }^{176}$ Escrito קאב'אנה.

${ }^{177}$ Entiendo que alude a la rapidez con la que se cambian de atuendo entre un número y otro.

${ }^{178}$ Por lo que dice luego entiendo que se refiere a la pareja femenina del tal Cavana.

179 Escrito ב'יסקונטי.
} 
en obligación me mete

de hablar esta semana

30 como hiće por Cavana;

y a la Alhambra también

dićen que cantan muy bien.

No sentí con mi oído

por darvos cuento rendido.

35 Ya vo ir en estos días

por oír las comedías

y haćervos un raporto

de los artistas de el porto.

Se refiere ahora Šalem a dos cantantes: Cavana, al que elogia; y Visconte, cuya opinión se reserva hasta que vuelva a escucharle otras varias veces. Menciona el Café Alhambra, del que yo misma me he ocupado ${ }^{180}$, ya que fue dañado por una bomba que hicieron explotar activistas búlgaros en 1903. A este café también se refiere Saporta ${ }^{181}$, haciendo una detallada mención de los artistas internacionales que allí actuaban; también nos dice que su nombre se lo dio un sefardí en memoria de Granada, la ciudad de sus antepasados, añadiendo que a este «café-chantant» los burlones le denominaban «café šeitán», es decir, 'café del diablo', y que en él se instaló el primer cinematógrafo de la ciudad. También Tomanas ${ }^{182}$ se refiere a este café, situado cerca del mar, señalando que allí se instaló el primer fonógrafo de Salónica; indica asimismo que en él actuaba el judío asquenazí Rosenkrantz y que el local subsistió hasta 1925.

\subsection{Más alabanzas}

El tercer poema, titulado Eloǵios merecidos, vio la luz en La Época 26:1287 (14 iyar 5661 / 8 maŷio 1901, pág. 3a), apareciendo esta vez sin la firma habitual de SS, pero Attias ${ }^{183}$-quien, probablemente por error, lo

\footnotetext{
${ }^{180}$ En Entre dos (o más) fuegos, cap. 7 B, núm. 40.

${ }^{181}$ En En torno de la Torre Blanca, págs. 158-159.

${ }^{182}$ En The Coffee-houses, págs. 23-24.

${ }^{183}$ En «Šelomó H. Šalem», núm. 31.
} 
fecha el 3 mayo-, sí lo tiene por suyo. Consta de 66 versos, que de nuevo son aleluyas, con la siguiente presentación: los vs. 1-48 van como versos largos de rima interna y separados por hemistiquios; los vs. 49-52 van como los anteriores pero sin espacios de separación y sin rima interna; los vs. 53-64 son versos cortos; y los vs. 65-66 van un poco retranqueados a la izquierda. Las separaciones entre grupos de versos es mía.

\section{Elogios merecidos}

1 Sin haćer mucha reṿuelta esta tadre dad la vyelta de parte de aquel café ande hay un buen bufé.

5 No hagáš mucho sonido, ahí toparéš un nido de una «Palomba» blanca que el alma vos aranca. Graciośa es a la verdad,

10 y hermośa en cuantidad; yo a ella topo diña de su niño y su niña. La impresión poco tura de ver la deśenvoltura

15 de esta que llaman Berta ${ }^{184}$, de aplauśos cubierta. Lo es ella cada tadre: ¡qué gusto para el padre! ${ }^{185}$. La su ỵoź es armoniośa

20 y su pośa es graciośa. ¡Qué ojada atrayante!, ¡qué mirada langüisante! No pretendo ser un fino ni menos un endivino.

25 Ma lo digo de agora que presto verná la hora de meldar en la gaćeta que la siñorina Berta y también su hermanico,

\footnotetext{
${ }^{184}$ Escrito בירטה.

${ }^{185}$ Las admiraciones cerradas están en el texto.
} 
30 llamado n' Naminico $^{186}$, ya figuran en las listas de los más grandes artistas y fueron aplaudidos y en los Estados Unidos...

35 Raramente me engaño, lo meldaréš fin un año.

A n’ Namín ${ }^{187}$ le digo esto, que él se coriǵe presto de este chico defeto:

40 haće muy negro efeto y una negra impresión: su mucha ex́aǵeración.

Las famías sin espanto pueden ir tanto en cuanto

45 a pasar dos tres tadradas sin haćersen coloradas. Lo que cantan es honesto, afirmar lo puedo esto.

Acorer, mancebos,

50 haćer sías angaǵé, al café dicho ariba, al Café des Etranǵé.

Al Petí Čham ${ }^{188}$, Abramico, conocéš al güerquećico,

55 trujo a los Gaspar Neva ${ }^{189}$, para mí es cośa mueva.

Con sentirlos una tadre ¿queréš que a mí me cuadre a hablar de ellos algo? ${ }^{190}$.

\footnotetext{
${ }^{186}$ Escrito ן" נייאמיניקו, es decir, Benyaminico, diminutivo de Binyamín.

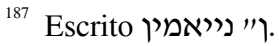

188 Escrito פיטי שיאם ניאדי ניאם.

189 Escrito גאספאר ניב'ה שיאיה.

${ }^{190}$ La interrogación cerrada está en el texto.
} 
60 Por escribirvos de largo cale ir tres cuatro većes, no vos digo cuatro meśes. En fin a esto cocluśión [sic]: cantan con mucha preciśión.

65 Haćer reclam no es mi inteción, los bianquinos cantan a perfección.

En este poema se nos mencionan otros dos locales: el Café des Etrangé, en el que se come bien (v. 4) y del que nada puedo decir; y el Petí Čham. Por lo que se dice (v. 53), el propietario o regente de este último local era un tal Abramico, que quizá habría que identificar con Abraham Maźlum al que se menciona en dos canciones editadas por Attias ${ }^{191}$. En la primera de ellas leemos (vs. 1-2 y 5-6): «Primavera en Salonico / cayí al café Maźlum / [...] / Y que no manques tú Fortuna / del café de Abram Maźlum»; y en la segunda (vs. 21-24): «No me manques tú Fortuna / del café de ande Maźlum / quitas ansias de mancebos / cuando tañes en el ut».

Sobre tal café, de principios del siglo XX y situado no lejos del mar, nos dice también Attias que era muy conocido y que estaba siempre lleno de público de día y de noche. Su popularidad residía en las cantantes que interpretaban en judeoespañol y en turco, y supone que la Fortuna mencionada fuera alguna sefardí cuyo verdadero nombre sería Maźal.

Se refiere Šalem a varios intérpretes. Dos actúan en el Café des Etranǵé: Berta, sobre la que se deshace en elogios, y su hermano Binyamín, joven al que reprocha su exageración. Quizá con la alusión a la «Paloma» (v. 7) se esté refiriendo a la misma canción española mencionada por Saporta ${ }^{192}$.

La otra pareja son los Gaspar - Neva del Petí Čham, a los que alaba, pero advierte que debe escucharlos en más ocasiones, lo que desde luego hizo, según vemos en el texto siguiente. Quizá al llamarlos bianquinos (v. 66), Šalem está queriendo decir que eran italianos, pero también puede ser que aluda a que se maquillaban la cara de blanco.

Resulta interesante su precisión de que a escuchar a Berta y a su hermano (vs. 43-48) pueden acudir las familias sin temor a ruborizarse, resaltando que lo que cantan es honesto. Ello viene a indicar que no todos

\footnotetext{
${ }^{191}$ En Cancionero judeoespañol, pág. 121, núm. 48; y págs. 216-217, núm. 123.

${ }^{192}$ Vid. mi comentario al texto 7 supra.
} 
estos cafés ofrecían espectáculos aptos para mujeres, y corrobora la procacidad reinante en algunos de ellos, según lo que nos describe Saporta ${ }^{193}$ :

En los «café-chantán», para atrayer la quilenteia [sic], el chalguí y la múśica no bastando para esto, se vía asentadas sobre una chica čena, mujeres en sirá que iban a cantar y a bailar con los quilentes [...].

Nos podemos imaginar lo que pasaba después de esos cantes y bailes.

\subsection{Alabanzas a los Gaspar - Neva}

El cuarto poema, titulado Al Petí Čham, apareció en La Época 26:1289 -el 9 corregido a mano sobre un 8- (28 iyar 5661 / 17 maŷio 1901, pág. $3 \mathrm{c}$ ), que esta vez sí va firmado SS al pie ${ }^{194}$. Consta de 20 versos, que son aleluyas, más otros cuatro, a modo de coda final y cuya presentación respeto, rimando los tres últimos en -ar.

\section{0. Éxito de los Neva}

1 Ya fui más de una tadre y yo no cale me detadre a dećirvos sin mucha fazón en «la coturiera un fresón».

5 En la grande $\mathrm{ru}^{195}$ rabisante lo haće tanto exitante que el hombre el más yelado cale se detenga el... ${ }^{196}$ lado ${ }^{197}$. ¡Bravo Neva!, hombre y mujer.

10 ¿Quién es que puedría escoǵer cuála es su mejor cantiga? ${ }^{198}$ :

\footnotetext{
${ }^{193}$ En En torno de la Torre Blanca, pág. 215.

${ }^{194}$ AtтiAs, «Šelomó Ḥ. Šalem», núm. 32.

${ }^{195}$ Escrito רו que quizá se trate de fr. rue 'calle', en cuyo caso tendríamos que entender «grande ru» como 'calle mayor, calle principal'; puede tratarse del nombre de una canción o de uno de sus números musicales.

${ }^{196}$ Los puntos suspensivos en el texto.

${ }^{197}$ Es decir, el número es tan divertido que la persona más impasible tiene que sujetarse los lados, los costados, para no partirse de risa.

${ }^{198}$ La interrogación cerrada está en el texto.
} 
que venga y que me lo diga.

A mí más de toda persona

«El riquiquí» ${ }^{199}$ me impresiona.

15 Sí, me impresiona, me gusta, me meneo como una susta ${ }^{200}$ y entero me apercanta «El Mulín Ruj́» cuando me canta. Estó triste, ahí me gusto ${ }^{201}$, 20 porque lo que cantan es justo.

Dunque ¿quién me puedría topar otro un par como Gaspar?

Como vemos, en este caso el poema está dedicado por entero a alabar a los Neva, hombre y mujer, intérpretes en el Peti Čham.

La afición de Šalem por esta pareja sigue el siguiente proceso: los escucha por primera vez el 8 de mayo de 1901 (texto 9, apdo. 5.3 supra) y declara su entusiasmo por ellos solo unos días después, en este texto del 17 de mayo; el 12 de julio de ese mismo año 1901 insiste en su afición por los Gaspar - Neva (final de texto 4, apdo. 3 supra); el 8 de noviembre de 1901 expresa su deseo de volver a verlos actuar (texto 6, apdo. 4.4 supra), deseo que se ve cumplido el 23 de enero de 1903, cuando dichos artistas regresan a Salónica (texto 11, apdo. 5.5 infra).

Nos indica ahora Šalem que entre sus canciones favoritas del repertorio de esta pareja están un llamado «El riquiquí» y también la canción francesa titulada «El Mulín Ruj», que quizá formara parte por aquellos años del repertorio del famoso cabaret parisino de Moulin Rouge, inaugurado en 1889.

De los Gaspar - Neva debo de nuevo agradecer a Aitor García Moreno la información que me ha proporcionado así como el siguiente cartel y la postal que incluyo más abajo.

\footnotetext{
199 Escrito ריקיקי.

${ }^{200}$ Escrito סוסטה; vid. NeHama, Dictionnaire, s.v. sustá, lo acentúo susta por mor de la rima.

201 Es decir, si estoy triste, allí se me pasan todas las penas.
} 


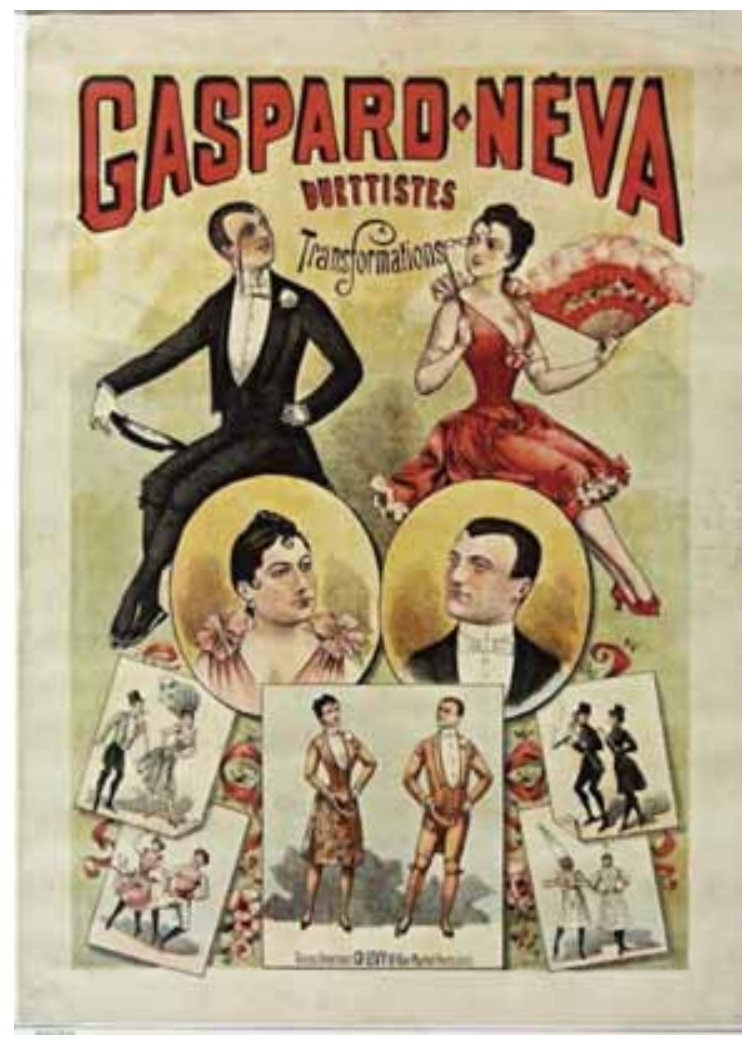

En la página web que indico en nota ${ }^{202}$ aparece esa deliciosa reproducción de un cartel de la pareja: él, con bigotito a la moda, está vestido de esmoquin, con monóculo y sombrero en mano; y ella, con pelo corto, viste un traje rojo, escotado, sin mangas, ceñido de cintura para arriba y con una amplia falda hasta las rodillas rematada con puntillas blancas. Calza zapatos rojos de tacón, y porta en una mano un amplio abanico también rojo y en la otra unos binóculos. Sobre ellos se dice: «Gaspard-Néva, duettistes à transformations»; bajo ellos aparecen sendo medallones con sus caras, bajo él la cara de ella y viceversa, y aún más abajo en un recuadro central y en dos más pequeños a cada lado aparecen cinco imágenes de los disfraces a cual más variopintos que llevan en algunas de sus actuaciones.

\footnotetext{
${ }^{202} \mathrm{http}: / /$ fr.muzeo.com/reproduction-oeuvre/gaspard-neva-duettistes-atransformations/anonyme.
} 
También los vemos en esta postal, en la que Gaspar parece amenazar con un bastón a su pareja.

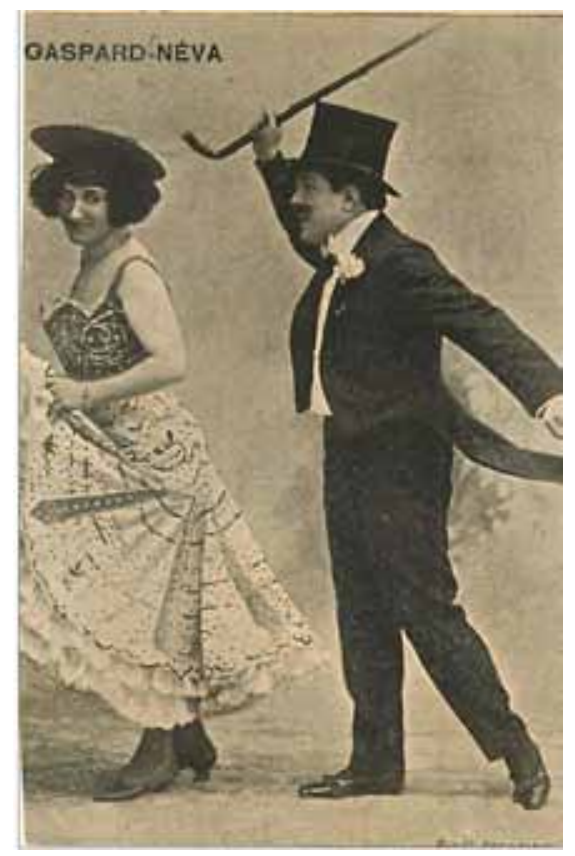

Sobre ellos el periódico Le Nouveau Lyon de 13 de octubre de 1894 en su sección «Courrier des Theatres» informa que en el Casino des Arts y entre otros artistas actuarán los ahora llamados Gaspare - Neva. Que su fama traspasó los límites de Francia lo vemos por un anuncio que aparece en el periódico The Straits Times de Singapur (pág. 4, col. 2), donde bajo el epígrafe «Advertisements» se anuncia para esa misma noche lo siguiente ${ }^{203}$ :

Town Hall / Gaspard Neva / The Famous Duettists. / From the "Ambassadeurs", Paris, the Alhambra, London and principal Music Halls, Europe.

${ }^{203}$ http://eresources.nlb.gov.sg/newspapers/Digitised/Article/straitstimes19040302.2 .44.2.aspx, propiedad de National Library Board de Singapur. 


\subsection{Más alabanzas a los Gaspar - Neva}

El texto, también mencionado por Attias ${ }^{204}$ y que yo debo a la amabilidad de Dov Cohen, se publicó con el título A la Olimpia y apareció en La Época 28:1373 (24 tebet 5663 / 23 de genayo 1903), como siempre firmado SS. Consta de 28 pareados y dice así:

\section{Los insuperables Neva - Gaspar}

1 Cored amigos, venid al Olimpia, todo lo malo ahí se alimpia: negra humor, tristeźa y probedad; probaldo y veréš la pura verdad.

5 Neva y Gaspar al más sufriente, con sus dulce yoź siempre sonriente, haćen por seguro relevar la frente; puede segurarlo el que fue preśente. Agora truǰeron repertorio muevo

10 que aplaudićen viejo y mancebo. «Clodín» y «Margó», dos muevos pedazos, cuálo que escojgás topas embarazos.

Las tadres las palmas no son menajadas, ganar se las haćen sus dulces ojadas.

15 Los gestos que haćen todos naturales, triste ahí entras y alegre sales. ¡Qué ricos vestidos, qué vestidos ricos!, quedan encantados y grandes y chicos. Todas las mujeres lo más de el tiempo

20 quedan contamplando [sic] vestido y cuerpo. Lleva de la moda corsé y calzado que saloniquiotas no han alcanzado. «Yo no me entiendo», ella dijo esto, cored corijarme un poco más presto.

25 Venid šaḅat todas, controlar mi dicha; si yo no vos veo, es una desdicha.

Hay también una otra que llaman Florica y canta muy bueno y es graciośica.

\footnotetext{
${ }^{204}$ En «Šelomó Ḥ. Šalem», pág. 335, núm. 41.
} 


\section{CONClusión}

Ya he manifestado en diversas ocasiones mis recelos acerca de las excelencias de la poesía sefardí «de autor» de los tiempos modernos, entendiendo por tales tiempos el último tercio del siglo XIX y el XX hasta la Segunda guerra mundial. Y, desde el punto de vista poético, debo reconocer que abomino de las estructuras poéticas de aleluyas y pareados, esquema de gran predicamento en el mundo francés y del que los sefardíes autores de esta poesía «a la moderna» usaron y abusaron, como es el caso de Šelomó Šalem. Pero una cosa son los gustos poéticos de cada uno y otra la curiosidad que debe guiar los caminos del investigador y del estudioso.

Reconocido eso, debo señalar que, pese a mis recelos y como ya he dicho en otro lugar ${ }^{205}$, sí distingo del saco general de esa poesía los poemas de contenido irónico y mordaz, como algunos de los que hemos visto, en los que, con mayor o menor fortuna según el estro poético de sus autores, sí se nos muestra la capacidad de la lengua judeoespañola para la burla y su expresividad a la hora de poner por escrito ideas mordaces e irónicas. Y, desde el punto de vista lingüístico, también nos muestran tales poemas los muy importantes cambios sufridos por el judeoespañol de esos tiempos modernos, en donde encuentran cabida una gran cantidad de italianismos y sobre todo de galicismos (vid. al respecto el Glosario).

Además, en lo que hemos leído hay otro asunto de gran interés: el mostrarnos la bulliciosa vida cultural de la Salónica de la época -y no me refiero al periódico- en la que un buen número de jóvenes poetas se entregaban a la tarea de modernizar la poesía judeoespañola. Y aún más, en este tipo de poemas encontramos, dicho por boca de estos poetas desaparecidos para siempre, muy interesantes datos reveladores del día a día de las comunidades sefardíes de los Balcanes, que son de gran valor para conocer su historia social.

Por último quiero señalar que mi propósito con este artículo es poner a disposición de los interesados en el panorama de los espectáculos musicales de la Salónica de aquellos tiempos unos textos un tanto recónditos, y ello con el fin de que los expertos en estas materias puntualicen mis palabras y rellenen los huecos que yo no he sabido complementar.

${ }^{205}$ Vid. Elena Romero, «Sátiras sefardíes salonicenses (con su poquito de misoginia) sobre las elecciones griegas de 1926», en Judeo Espaniol: Textos satíricos judeoespañoles de salonicenses o sobre salonicenses, eds. Rena MolHo, Hilary Pomeroy y Elena Romero (Thessaloniki: Ets Ahaim Foundation, 2011) págs. 68-90. 


\section{GLOSARIO $^{206}$}

achetar (it. accetare) 'aceptar' -- acorer 'correr, darse prisa' -- acostar oreja 'escuchar, prestar atención, hacer caso'.- adar (hb. אדר): sexto mes del calendario judío; tiene generalmente 29 días y su comienzo oscila entre el 1 de febrero y el 12 de marzo.- adefla 'amargura, tristeza'.- adío (it. addio) 'adios'.--adrezar (fr. adresser) 'dirigir, hacer llegar'.- afalago 'consuelo'.- afrito 'sufriente'.aharbar (hb. חרב héreb 'espada'; vid. DCECH, s.v. harbar) 'pegar, golpear'.aĵunta: en —— 'juntos, reunidos'; vid. nota 46.- aĵuntar 'reunir' -- alcuña (esp. alcuña, alcurnia, tc. künye) 'apellido'.- alguayar ( $c f$. esp. guay ¡ay!) 'gemir, lamentarse'.- amator 'amante, aficionado [de las artes, etc.]'.- amudición 'mudera, enmudecimiento, silencio'.- ande 'donde'.- angaǵé (fr. engagé) 'enganchado, cogido del brazo'.- apartar 'distinguir, diferenciar'.- apercantarse 'asombrarse, quedarse encantado, quedar embrujado'.- aranco 'pena, disgusto, dolor'.- 'arḅit (hb. ערבית): oración sinagogal vespertina.- arés 'al ras, en el borde'; vid. nota 54.- arestar (fr. arréter) 'acabar, concluir' -- armada (fr. armée) 'ejército'.- aśo (it. asso) 'as'; vid. nota 45.- atelier (fr. atelier) 'taller'.atirar (fr. attirer) 'atraer'.- atorgar 'reconocer, otorgar'.- aure 'aura'.- beato 'feliz'.- Bešchinar (tc. beş 'cinco' + çinar, çenar 'roble'): nombre de un conocido parque de Salónica.- beźer (tc. bez- 'cansarse, hartarse'): haćerse 'no poder más, descorazonarse, estar harto'.- bianquinos ( $c f$. it. sing. bianco 'blanco') 'blanquitos'.- bilieto (it. biglietto) 'billete, cupón para un sorteo'.biscornuda: vid. nota 96.- boca de alma: vid. nota 40.- bochorno: abrir un —- vid. nota 16.- bon jorno (it. buon giorno) 'buenos días'.- botica 'tienda'.boyicas (tc. sing. boya 'pintura, tintura') 'pinturitas, tintecitos'.- bročhura (fr. brochure) 'folleto'.- bruta (it. brutta) 'mala'.- buraco (prt. buraco) 'agujero, hueco'.- café-chantán (fr. café chantant) 'café cantante'.- caler (esp.) 'hacer falta, ser necesario, haber de, tener que'.- caño 'barro, suciedad, desperdicios' .capo (it. capo): — de año 'año nuevo, primero de año'.- cargarse (fr. se charger) 'encargarse'.- caridable (fr. charidable) 'caritativo'.- caro (it. caro) 'querido, amado'.- caronales: hablando de amigos 'amigos íntimos, muy cercanos, carnales'.- celibatario (fr. celibataire) 'soltero'.- čena (it. scena) 'escenario, escena'.- centea 'centella'.- chalguí (tc. çalgl) 'banda de música turca'.- charší (tc. çarşı) 'mercado'.- Cluḅ deś Intime (fr. Club des Intimes 'Club de los Íntimos'): vid. nota 66.- conhortarse (esp. conhortar) 'consolarse, reconfortarse'.- conquerencia ( $c f$. fr. conquérir) 'rivalidad, competencia'.-

${ }^{206}$ Recojo en el Glosario las palabras que, con criterios subjetivos, me han parecido no ser de comprensión inmediata para los lectores no especializados. En la indicación de las etimologías uso las siguientes abreviaturas: esp. español, fr. francés, hb. hebreo, it. italiano, ngr. neo-griego, y prt. portugués; en ocasiones, remito abreviadamente tanto al DCECH (= Joan Corominas y José Antonio Pascual, Diccionario crítico etimológico castellano e hispánico [6 vols., Madrid: Ed. Gredos, 1980-1991]) como al DRAE (= REAL Academia Española, Diccionario de la lengua española [23 a ed. Madrid 2014]). 
consumadores 'consumidores'.- controlor (fr. controleur) 'vigilante'.coredor 'casamentero'; vid. nota 105.- costreto (it. costretto): ser — 'estar obligado, constreñido'.- coturiera (fr. couturière) 'costurera'.- couple (fr. couple) 'pareja'.- creditores (it. sing. creditore) 'acreedores'.- cuartier (fr. quartier) 'barrio'.- cuento rendido (fr. compte rendu) 'informe'.- dečifrar (fr. déchiffrer) 'descifrar'.- depasar (fr. dépasser) 'sobrepasar'.- desfíar (fr. défier) 'desafíar'.- devente: nombre dado a cierta moneda turca.- dirito (it. diritto) 'derecho'.- diviśa 'apecto'.- duḅio (it. dubbio) 'duda'.- dunque (it. dunque) 'así pues, por tanto, en consecuencia'.- duramá (tc. doğrama) 'trabajo en madera, carpintería'.- edirnilí (tc. edirnili): natural de Edirne (Adrianópolis).eluenga 'lengua'.- elul (hb. אלול): duodécimo y último mes del calendario judío; tiene 29 días y su comienzo oscila entre el 8 de agosto y el 6 de septiembre.embarar (fr. barrer) 'borrar, tachar'.- empiegado (it. impiegáto) 'empleado'.emỵeźar (esp. avezar) 'enseñar'; 'aprender'.- encorajado (fr. encouragé) 'animado, alentado'.- endelantre: por —— 'en adelante'.- engajar (fr. engager) 'comprometer'.- ensuña 'rencor, resentimiento, malquerencia'.- escapar 'terminar, acabar'.- escarsos (esp. sing. escaso, it. sing. scárso) 'avaros, tacaños'.- escolarios 'estudiantes de colegios o de escuelas'.- escrujuir diente 'rechinar los dientes'.- espartirse 'repartirse, distribuirse'.- espiegación ( $c f$. it. spiegare) 'explicación'.- esprito (fr. esprit, it. spirito) 'espíritu' -- estampa (it. stampa) 'imprenta'.- estifa (ngr. $\sigma \tau i ́ \beta \alpha, \sigma \tau 0 \tilde{} \beta \alpha$ 'montón, pila'): vid. nota 89.Etrangé (fr. etranger) 'Extranjeros', nombre de un café.- evenimento (fr. sing. événement) 'acontecimiento, evento, suceso'.- faltida 'falta'.- fazón (fr. façon) 'modales, remilgos'.- felaj (tc. fellâh) 'campesino, de pueblo', se refiere a la música tradicional turca.- fiero 'hierro'; vid. mašcar.- figas: haćer — a alg. 'humillarle, provocarle'; vid. nota 22.- fišugos 'pesados, molestos'.- foya 'tumba, hoya' - gómito 'vómito'.- graciośamente ( $c f$. fr. grâce) 'amablemente, gentilmente'.- gruš (tc. guruş, kuruş) 'piastra', moneda turca de poco valor.gruta 'tienda' - güercos (esp. sing. orco, huerco 4 'a acep. 'diablo'): haćerse 'convertirse en enemigos'.- güerquećico 'diablillo'.- haćino ( $c f . D C E C H$, s.v. hacino) 'enfermo'.- hadrośos 'hipócritas, amanerados, estirados'.- haldiquera (cf. DCECH, s.v. faltriquera) 'faltriquera, bolsillo'.- hecho 'trabajo', 'asunto'.heg 'he aquí' .- heśitar (fr. hésiter) 'dudar, vacilar'.- ḥešván (hb. חשון): segundo mes del calendario judío; tiene veintinueve o treinta días y su comienzo oscila entre el 6 de octubre y el 4 de noviembre.- hoche (tc. hüccet) 'pagaré'; vid. nota 25.- impośantes (fr. sing. imposant) 'imponentes'.- Ištirá (tc. iştira 'compra, adquisición') 'Mercado de cereales'.- iyar (hb. אייר): octavo mes del calendario judío, tiene veintinueve días y su comienzo oscila entre el 12 de abril y el 11 de mayo.--jorno: vid. bon.- jovanoto ( $c f$. it. giovane 'joven') 'jovencito'.- kavanés (tc. sing. kahvehane) 'café, local para tomar café y otras bebidas'.- kislev (hb. כסליו): tercer mes del calendario judío; tiene 30 o 29 días y su comienzo oscila entre el 5 de noviembre y el 3 de diciembre.- langüisante (fr. languissante) 'lánguida'.- letra (fr. lettre): a la —_ (fr. á la lettre) 'al pie de la letra'; vid. nota 78.- luayala (fr. loyale) 'leal'.- luito 'luto'.- luviar 'llover'.- ma (it. ma, tc. ama) 'pero'.- magaćines (fr. sing. magasin) 'tiendas, almacenes'.- malgrado 
(it. malgrádo, fr. malgré) 'a pesar de'.- mancar (fr. manquer, it. mancare) 'faltar'.- manćía 'mancilla, desgracia, infortunio'.- manco (fr. manque, it. manco) 'menos'; en —_ 'en menos'.- mašcar fiero: vid. nota 19.- Maźal (hb. מזל 'suerte, fortuna'): nombre femenino.- meldadores 'lectores'.- meldar (esp.) 'leer'.- menajar (fr. ménager) 'manejar, tratar', 'organizar'.- menueśería (fr. menuiserie) 'carpintería'.- mestro 'jefe, patrón; maestro'.- meter(se) 'poner(se)'.- mientres: en — 'mientras tanto'.- minḥá (hb. מנחה): oración sinagogal de la tarde que es preceptivo recitar antes de la puesta del sol.- Mišlé (hb. משלי): nombre del libro bíblico de Proverbios.- miśmo (fr. même) 'también, incluso'.- Miŝráyim (hb. מצרים) 'Egipto'.- moḅilia (it. mobilia) 'mobiliario'.muḥtares (tc. sing. muhtar) 'jefe de un barrio o de una aldea; alguacil'.- Mulín Ruj́ (fr. Moulin Rouge): aquí nombre de una canción.- n’ Namín, n’ Naminico (cf. hb. בנימין Binyamín 'Benjamín'): vid. notas 186-187.- na (tc. $n a$, ngr. va) 'he aquí'.- nani: haćer —: vid. nota 158.- negro 'malo, malvado'; más 'peor' -- nisán (hb. ניסן): séptimo mes del calendario judío; tiene treinta días y su comienzo oscila entre el 13 de marzo y el 11 de abril.- niźam bedelí (tc. nizam bedeli): vid. nota 39.- nosos 'nosotros'.- Olimp (fr. Olymp): nombre de un café.- olmás (tc. olmaz 'equivocado, errado'): estar ——: vid. nota 164.- oreja: vid. acostar.- ornamiento (fr. ornement) 'adorno'.- oya: vid. nota 81.palmatoria 'palmeta'; vid. notas 125-126.- parientes (fr. parents) 'padres'.peǰe 'pescado, pez, peje'.- péndola 'pluma de escribir'.- penserio (it. pensiero) 'pensamiento'.- Petí Čham (fr. Petit Champ): nombre de un café.- plonjar (fr. plonger) 'hundir, sumir, sumergir'.- póbero (it. povero) 'pobre, desgraciado'.polemicar ( $c f$. fr. polémique 'polémica') 'polemizar, discutir'.- portreto (fr. portrait) 'retrato'.- prefación 'prefacio, prólogo'.- presto (it. presto) 'rápido, de prisa'.- preto 'negro'; 'moreno'.- pronto (it. pronto) 'preparado, dispuesto'.-

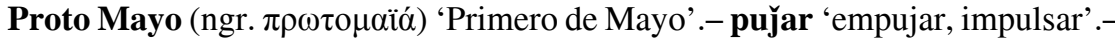
punto 'momento, segundo, instante'.- quierás (tc. sing. kira) 'alquileres, rentas'.- rabisante (fr. ravissante) 'maravillosa, encantadora, arrebatadora'.raporto (fr. rapport, it. rappòrto) 'informe'.- reclam (fr. réclame): haćer 'hacer propaganda, hacer publicidad'.- redijar (fr. rédiger) 'redactar' -- reflo 'suspiro, aliento'.- reǵim (fr. regime) 'régimen'.- regretado (fr. regretté) 'añorado, llorado'.- regretar (fr. regretter) 'lamentar, deplorar, sentir' .- regreto (fr. regret) 'pena, pesar, dolor'.- relevar (fr. relever) 'levantar'.- remarcar (fr. remarquer) 'notar, advertir, observar'.- rendir (fr. rendre) 'prestar un servicio, ayudar, contribuir al logro de una cosa'; rendirse 'dirigirse, ir' - - reportier (fr. e it. reporter) 'reportero, periodista'.- reśicar (fr. risquer) 'arriesgar'.- riquiquí: vid. nota 199.- robina (it. rovina) 'ruina' .- rosiñol (fr. rossignol) 'ruiseñor'.royo 'rubio, pelirrojo'.- ru: vid. nota 195.- Ruayal (fr. royale 'Real'): nombre de un café.- šabat (hb. שבת) 'sábado'.- šebat (hb. שבט): quinto mes del calendario judío; tiene 30 días y su comienzo oscila entre el 2 y el 31 de enero.šeitán (tc. şeytan) 'diablo, satanás' .- selaniclís (tc. sing. selânikli) 'saloniquiotas, habitantes de Salónica'.- šim'onim: vid. nota 13.- siñorina (it. signorina)

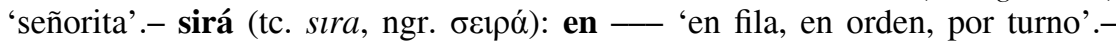
siván (hb. סיון): noveno mes del calendario judío; tiene 30 días y su comienzo 
oscila entre el 11 de mayo y el 9 de junio.- solanel (fr. solennel) 'solemne'.soliditá (it. solidita; fr. solidité) 'solidez'.- succeso (fr. succès) 'éxito'.- suhetar (fr. souhaiter) 'desear'.- sujeto (fr. sujet) 'tema, asunto'.- Sukot (hb. סוכות): fiesta de las Cabañuelas; una de las tres festividades mayores, de peregrinación en los tiempos bíblicos; comienza el 15 de tišrí y dura una semana, en la cual es preceptivo residir o sentarse a comer en cabañas construidas al efecto en jardines o terrazas.- suo (it. suo) 'suyo'.- supitaña ( $c f$. prt. supetão 'repentino') 'repentina, súbita'.- súpito 'subitamente, de pronto'.- susta (tc. susta) 'resorte, muelle'; vid. nota 200.- suvenir (fr. souvenir) 'recuerdo'.- Talmud Torá (hb. תלמוד תורה nombre que recibían las escuelas comunales, que se dedicaban fundamentalmente a la enseñanza religiosa.- tamuź (hb. תמוז): décimo mes del calendario judío; tiene 29 días y su comienzo oscila entre el 10 de junio y el 9 de julio.- tebet ( $\mathrm{hb}$ ): cuarto mes del calendario judío; tiene 29 días y su comienzo oscila entre el 4 de diciembre y el 2 de enero.- tenerse 'mantenerse, permanecer'.- tiĵaret (tc. ticaret 'comercio'): vid. nota 39.- tišrí (hb. תשרי): primer mes del calendario judío, su comienzo oscila entre el 6 de septiembre y el 5 de octubre.- Tnŝbh: vid. nota 67.- tomar el daño: vid. nota 28.- Torá: vid. Talmud.- torno 'turno, ocasión, momento'; a sus —_ 'a su vez'.- tram (fr. tram) 'tranvía' - - turar 'durar'.- ut (tc. ut, ud) 'laud'.- vaśada: vid. nota 23.vavá (ngr. $\beta \alpha \beta \alpha$ ) 'abuela'; vid. nota 106.- velludo 'terciopelo'.- yierbos ( $c f$. $D R A E$, s.v. verbo) 'palabras'.- yero 'error, equivocación, yerro'.- yol parasí: vid. nota 39.

Recibido: 01/11/2016

Aceptado: 13/03/2017 